\title{
A exposição como múltiplo: lições de uma mostra norte-americana em São Paulo, 19471
}

\begin{abstract}
Helouise Costa ${ }^{2}$
RESUMO: No ano de 1947, a Biblioteca Municipal de São Paulo apresentou a exposição Fotografia Artística preparada pelo Museu de Arte Moderna de Nova York com consultoria técnica de Andreas Feininger. Tratava-se de uma mostra didática de reproduções fotográficas impressas em painéis, acompanhadas de textos, que reunia imagens de autoria de fotógrafos como Erich Salomon, Ansel Adams e Henri Cartier-Bresson, entre outros. Originalmente denominada Creative Photography foi produzida como múltiplo para que pudesse ser comercializada e exibida simultaneamente em diversas localidades. Este artigo visa analisar a mostra Fotografia Artística, buscando situá-la em meio às profundas transformações culturais do segundo pós-guerra, particularmente em relação às ações culturais norte-americanas realizadas no Brasil no período, às tratativas para a criação dos primeiros museus modernos no país e ao uso das técnicas de reprodutibilidade fotográfica no campo da arte.

PALAVRAS-CHAVE: Fotografia artística. Biblioteca Municipal de São Paulo. Museu de Arte Moderna de Nova York. Exposição didática. Andreas Feininger. Fotografia criativa.

ABSTRACT: In 1947, the Municipal Library of São Paulo hosted the exhibition Artistic Photography, prepared by the Museum of Modern Art of New York with Andreas Feininger as the technical adviser. It was an educational show with photographic reproductions printed on panels and accompanied by texts, with images made by photographers such as Erich Salomon, Ansel Adams, and Henri Cartier-Bresson, amongst others. Originally entitled Creative Photography, it was conceived as a multiple exhibition, one that could be purchased and displayed simultaneously in several locations. The present article aims to analyze the show Artistic Photography and seeks to contextualize it in the midst of the profound cultural transformations of the aftermath of World War II. The American cultural activities held in Brazil in the period, the negotiations for the creation of the first museums of modern art in the country and the use of photographic reproduction techniques in art will be considered in this context.

KEYWORDS: Artistic Photography. Municipal Library of São Paulo. Museum of Modern Art of New York. Didactic exhibition. Andreas Feininger. Creative Photography.
\end{abstract}

Anais do Museu Paulista. São Paulo. N. Sér. v.22. n.1. p. 107-132. jan.- jun. 2014.

1. A primeira versão deste ensaio foi desenvolvida no âmbito do Projeto Temático da FAPESP, denominado Lugares e modos críticos da arte contemporânea nos museus (2005-2009) e foi apresentada no XXX Colóquio do Comitê Brasileiro de História da Arte em outubro de 2010. Esta é uma versão revista e ampliada que parte de novos pressupostos, utiliza fontes complementares e propõe outros parâmetros de análise.

2. Docente e curadora do Museu de Arte Contemporânea da Universidade de São Paulo. E-mail: <helouise@usp.br>. 
3. Ver Antonio Pedro Tota (2000, p. 92; 183-193). Segundo o autor, o ano de 1944 foi um marco na mudança da política dos Estados Unidos para a América Latina. Devido aos avanços favoráveis aos aliados na conjuntura da guerra e à consequente diminuição do poder de influência dos países do Eixo na América Latina, houve um esvaziamento gradativo da Política da Boa Vizinhança, o que levou ao enfraquecimento do Office of the Coordinator of Inter-American Affairs (OCIAA), à saída de Nelson Rockefeller da direção e à sua extinção definitiva em maio de 1946.

4. Devemos lembrar que tanto o Museu de Arte Moderna de São Paulo quanto a Bienal de São Paulo, inaugurada em 1951, foram instituições organizadas a partir do estreitamento de relações entre a burguesia industrial brasileira e corporações norte-americanas, unidas pelos ideais de um projeto civilizatório comum que envolvia, entre outras, a preocupação de educar o público para a arte moderna. Ver Oliveira (2001).

5. Sobre o fenômeno da internacionalização do campo da arte moderna ver: Maria Lúcia Bueno (1999).

6. Essa exposição foi analisada pela primeira vez pela pesquisadora Heloísa Espada e desde então tornou-se referência importante para os estudos sobre a presença da fotografia no circuito paulistano no final da década de 1940. Ver Heloisa Espada (2006).

7. Nelson Rockefeller (19081979) assumiu o cargo de presidente do MoMA em 1939, tendo se afastado em janeiro de 1941 para assumir a direção do OCIAA. Em 1944, deixou o OCIAA para atuar como assistente do Secretário de Estado para Assuntos Latino-America-
A atuação norte-americana no Brasil no campo da arte e da cultura ao longo da década de 1940 abarca desde as ações implementadas no âmbito da Políica da Boa-Vizinhança, durante a Segunda Guerra Mundial, até as iniciativas do imediato pós-guerra que remontam ao início da Guerra Fria. Se o objetivo no primeiro momento era obter, em caráter de urgência, a adesão do Brasil à causa aliada por meio das ações do Office of the Coordinator of Inter-American Affairs (OCIAA), o chamado Birô Americano, vencida a guerra pretendia-se garantir uma influência mais duradoura da cultura norte-americana no país a médio e longo prazo $^{3}$. Diversas ações culturais na América Latina tiveram continuidade e outras chegaram mesmo a ser iniciadas após a extinção do OCIAA, em função dos interesses de determinados grupos que mantiveram em pauta o discurso em defesa do pan-americanismo. Esse foi o caso do apoio norte-americano à criação de instituições culturais locais, a partir do estreitamento de relações com artistas, intelectuais e agentes culturais formadores de opinião ${ }^{4}$. Uma preocupação central do período entre nós foi a busca de atualização e internacionalização das artes, expressa tanto nas iniciativas individuais dos artistas, quanto no trabalho coletivo de grupos responsáveis por programas institucionais e governamentais ${ }^{5}$.

É nesse cenário que iremos situar a exposição Fotografia Artística, produzida pelo Museu de Arte Moderna de Nova York (MoMA) e apresentada na Biblioteca Municipal de São Paulo no período de 02 a 18 de julho de $1947^{\circ}$. Este artigo visa fornecer parâmetros para uma avaliação da importância da exposição, buscando identificar o contexto de sua produção, objetivos, públicoalvo e a recepção que obteve no ambiente paulistano. Para tanto iremos recorrer à documentação depositada nos arquivos do Museu de Arte Moderna de Nova York, aos escritos do fotógrafo Andreas Feininger e a artigos veiculados em publicações especializadas na ocasião.

Antecedentes

A vinda de Nelson Rockefeller ao Brasil, em novembro de 1946, acelerou o processo de implantação dos museus modernos no país. Rockefeller, que havia retomado a presidência do Museu de Arte Moderna de Nova York naquele ano, trouxe treze obras de arte para serem doadas aos futuros museus brasileiros como uma forma de manifestar concretamente o seu apoio e o da instituição que dirigia ${ }^{8}$. A sua visita rendeu uma reunião com a comunidade local de artistas e intelectuais na Biblioteca Municipal de São Paulo, instituição dirigida por Sérgio Milliet, na qual foi realizada a cerimônia de doação simbólica das obras. Na ocasião foi decidida a criação de uma comissão, a fim de agilizar o projeto de implantação de um museu de arte moderna na cidade, tendo como referência o seu congênere norte-americano?

No bojo das articulações políticas para a criação de um museu de arte moderna em São Paulo destaca-se o papel exercido por Sérgio Milliet ${ }^{10}$. Admirador assumido da cultura norte-americana, Milliet viajou aos Estados Unidos em 1943 
a convite do OCIAA, durante a vigência da Política da Boa Vizinhança, incumbidose de divulgar no Brasil a arte daquele país ${ }^{11}$. Independente dessa ação ter sido patrocinada, uma das principais preocupações de Milliet residia justamente na educação do público para a arte moderna, tanto nacional quanto estrangeira, o que ele veio a colocar em prática ao assumir a direção da Biblioteca Municipal, em 1943, como nos conta o crítico Luís Martins:

Nomeado diretor da Biblioteca Municipal, o ilustre escritor não poderia deixar de imprimir ao seu importante departamento uma feição de interesse pelas belas-artes. Assim é que, contando com o apoio do prefeito Prestes Maia, organizou uma interessante exposição permanente de reproduções de quadros célebres no saguão de entrada do grande edifício da rua da Consolação. A iniciativa é útil e demonstra uma inteligente percepção da importância das bibliotecas como instrumentos práticos de vulgarização cultural. Com a nossa precariedade triste em matéria de museus, não podemos dar ao povo a menor oportunidade de um contato mais ou menos íntimo com a arte. Com a sua mostra permanente de boas reproduções, a Biblioteca atenua essa falta ${ }^{12}$.

Sérgio Milliet daria continuidade à sua iniciativa de "vulgarização cultural" com a criação da Seção de Arte na Biblioteca Municipal aberta ao público em janeiro de 1945, para cuja direção nomeou Maria Eugênia Franco, escritora e crítica de arte. Franco incumbiu-se da organização de exposições, priorizando a exibição de originais de artistas modernistas brasileiros já consagrados. Havia ainda a preocupação de expor a produção de jovens artistas locais e dar continuidade às mostras didáticas de reproduções de obras estrangeiras. As atividades da Seção resultaram na constituição de um acervo de arte moderna brasileira que viria a ser o primeiro acervo público dessa natureza no país. Em um período "pré-museológico"13, como assim o define a própria Maria Eugênia Franco devido à inexistência de museus modernos na cidade, a Seção de Arte da Biblioteca Municipal contribuiu de maneira significativa para a atualização de artistas, bem como para a educação do público interessado em arte em geral. Como bem aponta Annateresa Fabris, a Seção de Arte funcionou como "um embrião do tão sonhado museu de arte moderna"14.

A tomar pelas diretrizes gerais do programa implantado pela dupla Milliet e Franco na Biblioteca Municipal parece ser possível afirmar que o caráter didático da exposição Fotografia Artística era perfeitamente compatível com os propósitos da Seção de Arte. Para aprofundarmos nossa análise, no entanto, precisamos investigar mais detidamente o conceito que norteou o projeto da mostra elaborado pelo Museu de Arte Moderna de Nova York (MoMA) e sua adaptação para itinerância.

A concepção original da exposição Fotografia Artística

A exposição Fotografia Artística, apresentada em São Paulo, foi concebida com o título original de Fotografia Criativa (Creative Photography) pelo Departamento de Exposições Itinerantes (Department of Circulating Exhibitions) do nos. Cabe ressaltar que ele era herdeiro da Standard Oil Company, multinacional da área de exploração de petróleo que mantinha negócios de vulto em diversos países latino-americanos e, portanto, tinha interesses na região que iam muito além do âmbito da cultura. Ver Antônio Pedro Tota (2000).

8. As obras ficaram provisoriamente sob a guarda do Instituto dos Arquitetos do Brasil e foram depois distribuídas entre o Museu de Arte Moderna de São Paulo e o Museu de Arte Moderna do Rio de Janeiro. Aquelas originalmente destinadas ao MAMSP encontram-se hoje no acervo do MAC-USP, entre as quais $A$ bestialidade avança de George Grosz (1933), Primavera de Marc Chagall (1938/1939) e Móbile amarelo, preto, vermelbo e branco de Alexander Calder, s.d..

9. A bibliografia sobre a criação do MAMSP é extensa. Destaco aqui apenas os trabalhos de Ana Paula Nascimento (2003) e Annateresa Fabris (2008), utilizados neste artigo.

10. Sérgio Milliet (18981966) era sociólogo de formação e crítico de literatura, tendo se tornado posteriormente crítico de arte. Integrava o grupo de intelectuais que assumiu a gestão das diversas seções do Departamento Municipal de Cultura e foi designado, em 1935, para dirigir a Divisão de Documentação Social e Histórica. Em 1943, assumiu a direção da Biblioteca Municipal onde permaneceu até 1959 , quando se aposentou. Sobre Sérgio Milliet, ver Lisbeth Rebollo Gonçalves (1992).

11. Ao retornar ao Brasil, Milliet publicou o livro Pintura norte-americana (1943), além de realizar palestras e produzir textos para a grande imprensa sobre temas correlatos. 
12. Cf. Luís Martins. Pintura e poesia. Diário da Noite, 29/01/1944; In: Ana Luísa Martins e José Armando Pereira da Silva (2009, p. 92). Infelizmente, não foi possível obter informações mais detalhadas sobre o conteúdo dessa exposição, que deixou de ser permanente a partir da criação da Seção de Arte, cedendo lugar a outras mostras.

13. Termo utilizado por Maria Eugênia Franco em depoimento a Lisbeth Rebollo Gonçalves em março de 1977. Apud Ana Paula Nascimento (2003, p.79).

14. Cf. Annateresa Fabris (2008, p.15).

15. Cf. The Museum of Modern Art Archives, NY, Department of Circulating Exhibitions Records. Serie II: Exhibitions, 1931-1958.

16. Cf. The Museum of Modern Art Bulletin (1954, p.10). Tradução da autora.

17. Cf. The Museum of Modern Art Archives, NY, CE II.1.49.1.1.

18. Não tivemos acesso às estatísticas de venda e aluguel das exposições múltiplas. Consta, no entanto, que em 21 de dezembro de 1944 foram encomendadas 500 cópias da exposição Creative Photography, retificando um pedido anterior de 200 exemplares. $O$ aumento em mais de $50 \%$ da quantidade anterior parece indicar que houve uma demanda superior ao que fora previsto inicialmente pelo museu. Cf. The Museum of Modern Art Archives, NY, CE II.1.49.1.1.

19. Elodie Courter (19111994) formou-se em história da arte e começou a trabalhar no MoMA em 1933 como voluntária nas ações educativas. Contratada em 1935, dois anos depois se tornaria a primeira diretora do recém-inaugurado $D e$ -
MoMA ${ }^{15}$. Apresentada ao público pela primeira vez no próprio auditório do museu, entre 07 e 25 de março de 1945, integrava um novo programa de exposições juntamente com outras três mostras:

A série de exposições múltiplas consiste em painéis de peso reduzido, nos quais são montadas reproduções coloridas, fotografias, desenhos ou diagramas, reproduzidos em quantidade para aluguel ou venda, acompanhados por comentários rápidos. Oferecidos pela primeira vez durante a estação de 1943-1944, incluem os títulos Olhe para a sua vizinhança [Look at your neighborhood] (...), Fotografia Criativa [Creative Photography], Elementos de design [Elements of design] e $O$ que é pintura moderna? [What is modern painting], que delineiam as vertentes importantes dos últimos 75 anos $^{16}$.

A funcionalidade do sistema era fundamental no programa de "exposições múltiplas". No caso da mostra Fotografia Criativa os painéis mediam cerca de $76 \mathrm{~cm} \times 100 \mathrm{~cm}$ e o conjunto, já acondicionado em embalagens especialmente projetadas para facilitar o transporte, pesava cerca de $20,40 \mathrm{~kg}^{17}$. Diferentemente das exposições itinerantes de obras originais, o novo programa utilizava técnicas de reprodução fotomecânicas. Tratava-se de exposições formadas de painéis impressos com tiragens de dezenas ou centenas de exemplares, conforme a necessidade, com potencial de atendimento simultâneo a um grande contingente de público ${ }^{18}$. $O$ programa de exposições múltiplas visava responder a uma demanda específica como explica Elodie Courter, primeira diretora do Departamento de Exposições Itinerantes ${ }^{19}$ :

O desenvolvimento da nova técnica de exposições múltiplas surgiu como resultado de um esforço de suprir a crescente demanda vinda de muitas partes do país por pequenas exposições compactas e inteligíveis que pudessem ser transportadas de maneira fácil e barata (...). Além da necessidade de mostras de baixo custo as exposições múltiplas atendem outra demanda igualmente recorrente. Muitas vezes no passado tinhamos que recusar solicitações porque as exposições eram requeridas para mais lugares do que nós podíamos responder com uma única mostra. Não raro tínhamos 50 ou 60 solicitações para uma exposição pequena (...). Com as novas exposições múltiplas não só todas essas demandas podem ser atendidas, mas no caso delas serem compradas ao invés de alugadas, a organização [que a comprar] pode fazer circular a exposição por outras organizações em sua própria localidade ${ }^{20}$.

público-alvo dessas mostras eram organizações comunitárias e instituições educacionais, abrangendo escolas de ensino médio, faculdades, bibliotecas, pequenos museus, clubes, sindicatos, associações fotográficas ou quaisquer outros grupos organizados que manifestassem interesse por seus conteúdos. Durante a Segunda Guerra Mundial consta que algumas delas chegaram a ser apresentadas em hospitais e acampamentos militares ${ }^{21}$. As pranchas deviam ser fixadas nas paredes, dispostas em vitrines ou apoiadas em suportes adaptados, dependendo das características do espaço onde seriam apresentadas. Exibidos quase sempre em forma de exposição, os painéis podiam servir também como suporte visual para palestras ou ainda material de estudo. 
A qualidade técnica das reproduções incluídas nas exposições múltiplas era sempre enfatizada nos textos de divulgação do MoMA e chegou a ser usada como argumento na correspondência enviada ao fotógrafo Ansel Adams com o pedido de autorização para a reprodução de duas de suas fotos na exposição:

Um processo de gravura sem retícula torna possível facsímiles de fotografias com menos de cinco por cento de perda da qualidade original. Nós o consideramos de longe muito mais satisfatório do que o método usual de reprodução usado até mesmo nas melhores publicações de fotografia 22

Adams, conhecido por sua preocupação com a perfeição técnica de suas cópias fotográficas, parece ter aprovado o resultado ao aceitar participar do projeto ${ }^{23}$. Nos bastidores do museu esse tema esteve presente também na extensa troca de correspondência entre os responsáveis pelo novo programa de exposições e os profissionais da empresa escolhida para realizar a impressão dos painéis, a Illinois Photo-Gravure Company. As discussões entre as partes recaíam, em sua maioria, sobre os processos mais adequados para se reproduzir cada tipo de imagem, a relação entre a qualidade e o custo das reproduções, assim como o custo-benefício no caso de haver reimpressão ${ }^{24}$. Estava em jogo não só a imagem do museu, que iria associar a sua marca institucional à qualidade daquele produto, mas também 0 interesse que as exposições poderiam despertar, pois eram destinadas à venda ou aluguel e, portanto, constituíam uma fonte potencial de renda para o museu ${ }^{25}$. No caso da Fotografia Criativa adotou-se a aplicação de vermelho e azul claro como cores de fundo nos painéis, o que nos leva a supor que o objetivo teria sido conferir maior interesse visual à exposição, já que as imagens eram em preto e branco e todas as outras exposições do programa continham reproduções em cores $^{26}$.

Entre 1945 e 1946, o MoMA contou com o apoio da National Gallery de Washington para a preparação de versões da exposição Fotografia Criativa, em espanhol e português, a fim de possibilitar a sua itinerância pela América Latina. Se levarmos em conta esse recorte geográfico específico, concluise que a versão em português foi produzida especialmente para ser apresentada no Brasil.

\section{Fotografia artística: a exposição apresentada em São Paulo}

A vinda da exposição Fotografia Artística ao Brasil, em 1947, contou com o apoio do Departamento Municipal de Cultura, da União Cultural BrasilEstados Unidos, do Foło Cine Clube Bandeirante, do Clube de Cinema de São Paulo e da revista Íris ${ }^{27}$. Uma edição especial da Íris, dedicada aos Estados Unidos, veiculou um encarte com as reproduções de todos os painéis apresentados na Biblioteca Municipal, documento que nos permite reconstituir detalhadamente o conteúdo da exposição composta por doze painéis nomeados individualmente ${ }^{28}$ (Figuras 1 a 12): partment of Travelling Exhibitions. Courter, que passaria depois a assinar Osborn, deixou o museu em 1947, passando a realizar trabalhos de forma independente. Em 1953, lançou um manual sobre mostras itinerantes pela UNESCO a partir de sua experiência pioneira. Ver Elodie Courter Osborn. Manual of Travelling Exhibitions. Paris: UNESCO, 1953. Biografia disponível em: http://www. moma.org/explore/publications/modern_women/ history\#lexicon8, acesso em 31/03/2014.

20. Trecho do release New technique of multiple circulating exhibitions on display at Museum of Modern Art, p.1. Cf. The Museum of Modern Art Archives, NY, CE II.1.49.1. Tradução da autora.

21. Folder de divulgação da mostra Creative Photography. Cf. The Museum of Modern Art Archives, NY, CE II.1.49.1.1.

22. Correspondência datada de 16 de Outubro de 1944. Cf. The Museum of Modern Art Archives, NY, CE II.1.49.1. Tradução da autora.

23. Ansel Adams (19021984) publicou três livros nos quais sistematizou de maneira rigorosa os procedimentos técnicos para a produção de fotografias em preto e branco: $A$ cópia, $O$ negativo e A câmera. Os três foram lançados no Brasil em 2000, 2001 e 2006, respectivamente.

24. A documentação do museu indica que as reproduções de obras de arte do acervo eram feitas em diferentes técnicas, de acordo com as características dos originais e podiam ser em litografia, off-set, silk-screen ou colotipia. Cf. The Museum of Modern Art Archives, NY, CE II.1.49.1.1. Para a exposição Fotografia Cria- 
tiva optou-se pela colotipia, processo de impressão a tinta obtido por meio de uma matriz de origem fotográfica que resulta em imagens de grande qualidade técnica. A respeito desse processo, ver Bertrand Lavédrine (2007, p. 192-193).

25. Consta no formulário de requisição, anexo ao folder de divulgação da mostra, que ela era disponibilizada apenas para venda e custava U\$ 25.00. Já a exposição What is modern painting? era vendida por U $\$ 60.00$ e alugada por U\$12.00. Cf. The Museum of Modern Art Archives, NY, CE II.1.49.1.1.

26. É possível supor que a escolha do vermelho e do azul para o fundo dos painéis tenha relação com as cores da bandeira norte-americana, o que não foi possível comprovar. Cf: folder de divulgação da exposição. The Museum of Modern Art Archives, NY, CE II.1.49.1.1. As reproduções em preto e branco eram impressas diretamente sobre os painéis, ao passo que as imagens em cores tinham que ser impressas separadamente e depois coladas.

27. Não foi possível levantar a contribuição específica de cada um desses agentes para a vinda da mostra ao Brasil.

28. Reprodução dos quadros expostos na Biblioteca Municipal de São Paulo (1947, p. 29-40). Este encarte era sanfonado e uma vez destacado da revista podia servir como uma espécie de cartaz, o que permitia ampliar ainda mais as possibilidades de difusão da mostra. Infelizmente os painéis da exposição enviada ao Brasil não foram encontrados, seja na União Cultural Brasil-Estados Unidos, no Foto Cine Clube Bandeirante ou na Biblioteca Mário de Andrade.

\section{Fatagrafia Artistica}

EXPOSIÇÃO PREPARADA PELO MUSEU DE ARTE MODERNA, DE NOVA YORK, COM O AUXILIO TÉCNICO DE ANDREAS FEININGER.

Reprodução dos Quadros expostos na Biblioteca Municipal de São Paulo

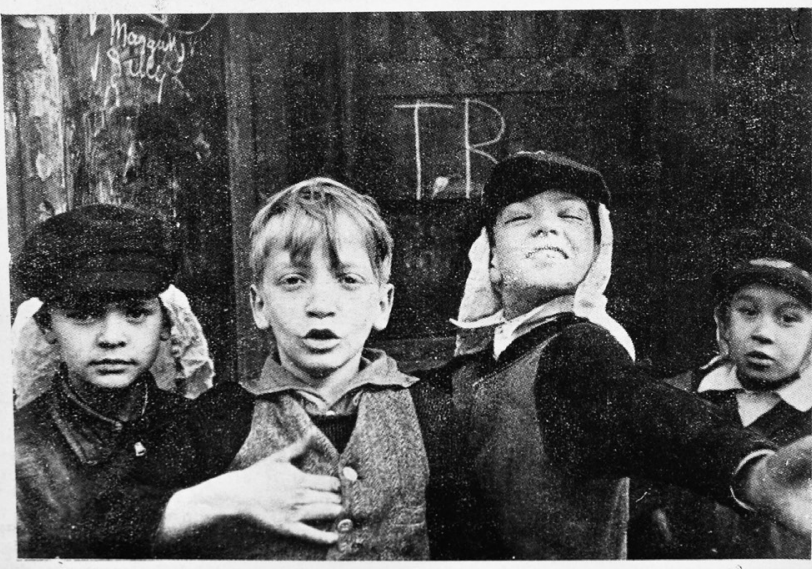

"Dramática... sem interêsse. de grande sensibilidade... brilhante... verdadeira... falsa..." tais são os epítetos empregados constantemente em relaçã a fotografias tomadas com fechar mecânico do obturador, o que indica que para muitos de nós a fotografia não é sòmente um processo científico de retratar algo, mas sim um Meio de Expressão.

A máquina fotográfica é um aparelho de grandes possibilidedes, pcrém, o fotógrafo, como qualquer outro artista, é mais importante que os instrumentos por êle usados. 0 fotógrafo domina a expressão e o significa to da imagem que retrata.

Helen Levitt: Manobras Militares.

Figura 1 - Fotografia Artística. Primeiro painel da exposição Fotografia Artística, Biblioteca Municipal de São Paulo, 1947. Íris, São Paulo, n.6, jun. 1947. Biblioteca da Cinemateca Brasileira, MinC, São Paulo.

\section{O FOTÓGRAFO É UM ARTISTA}

Quando o fotógrafo domina o seu aparelho fotográfico, o assunto da sua fotografia, a maneira tece, são de sua moscolha.

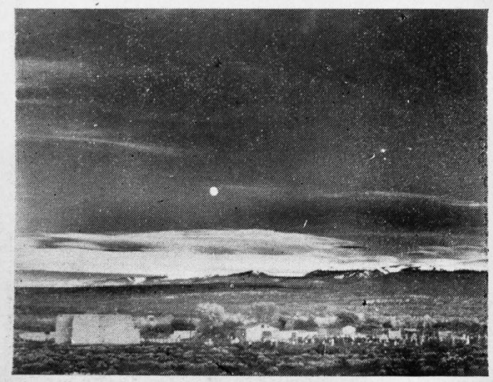

Anmel Adams: Nascer da Lua, Novo México.

O mistério de uma vasta planície vazia.

Todos nós temos visto essas coisas com os nossos próprios olhos, e, no entanto, cada uma dessas rotografias tem o seu caráter especial; a sua finade terem fotógraf essa transic̃ as fotografias. Como fez o gem intencional?

Figura 2 - O fotógrafo é um artista. Segundo painel da exposição Fotografia Artística, Biblioteca Municipal de São Paulo, 1947. Íris, São Paulo, n.6, jun. 1947. Biblioteca da Cinemateca Brasileira, MinC, São Paulo.

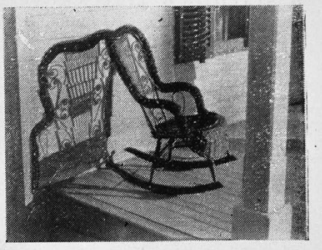

Ralph Steiner: Baroeo Rural Ame0 desenho feito pela sombra de uma cadeira de balanço.

0 rosto de umas erian-

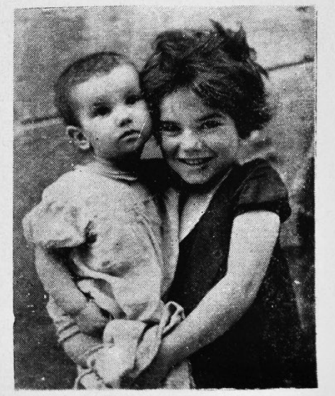

Fotografia da Marinha dos E. U., 
Um bom fotógrafo utiliza tanto a capacidade, como as deficiências da sua máquina fotográfica.

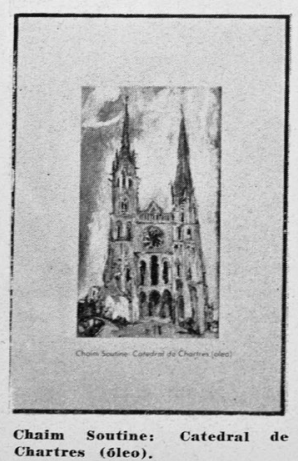

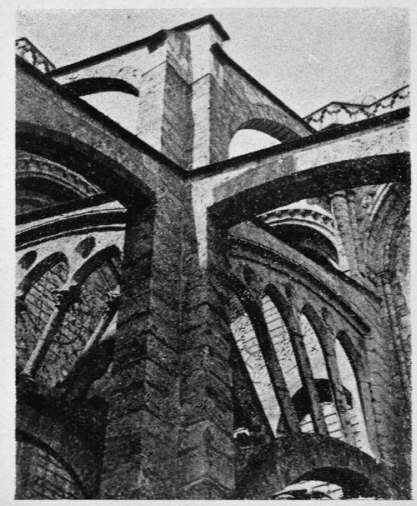
Charlex Shceler: Catedral de Chartres (foto-
grafin)

A téenica pode ser aprendida nos livros e nas não são essenciais para se tomar uma boa fotografia. Mas é importante saber o QUE SE QUER E COMO CONSEGUf-LO.

Figura 3 - Trabalha com um aparelho mecânico. Terceiro painel da exposição Fotografia Artística, Biblioteca Municipal de São Paulo, 1947. Íris, São Paulo, n.6, jun. 1947. Biblioteca da Cinemateca Brasileira, MinC, São Paulo.

O SEU MEIO DE EXPRESSÃO É UMA ESCALA DE VALORES

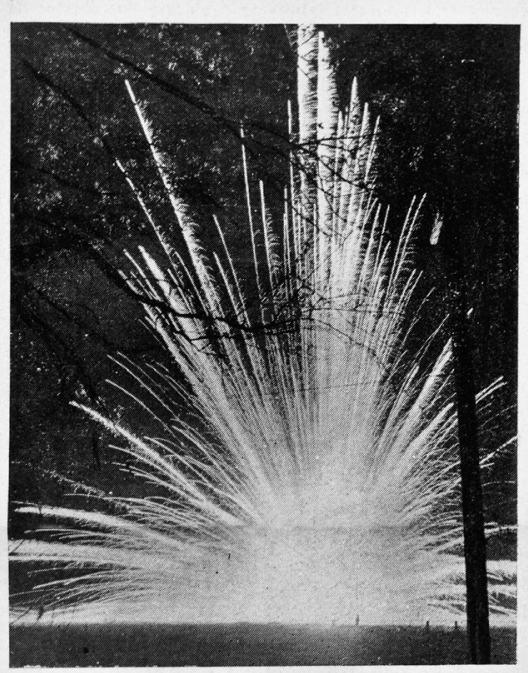

Na fotografia de branco e negro o fotografo artista domina a proporção da luz e sombra em sua fotografia e o contraste entre ambas. De um branco até um negro profundo passando pelas de escolher. As duas fotografias aqui incluidas exprose tem assunto em têrmos opostos: a explosão de uma bomba de seu nésio em contraste violento do negro e do branco, e a de magda atmosfera de uma tempestade de poeira em cinzents apenas.

Andreas Feininger: Explosño de uma Bomba de Maznésio.

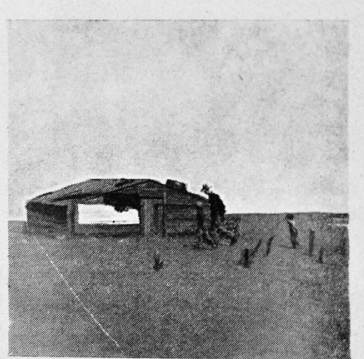

Arthur Rothstein: Fazendeiro e seus rihbs
numa Tempestade de Poeira em Oklahoma

As condições da luz representam parte importante na determinação dos valores numa fotografia. A maneira pela qual a luz cai sôbre o objeto determina a properção de luz e sombra na fotografia. o fotógrafo que revela e imprime as suas próprias otografias domina ainda mais os valores por meio da relação entre o tempo da revelação, e o tipo e papel usado na impressão.

Figura 4 - $O$ seu meio de expressão é uma escala de valores. Quarto painel da exposição Fotografia Artística, Biblioteca Municipal de São Paulo, 1947. Íris, São Paulo, n.6, jun. 1947. Biblioteca da Cinemateca Brasileira, MinC, São Paulo. 
ESCOLHE O SEU ASSUNTO

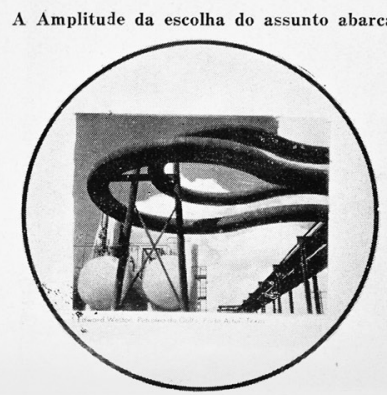

Edward Weston: Petróleo do Gôlfo,
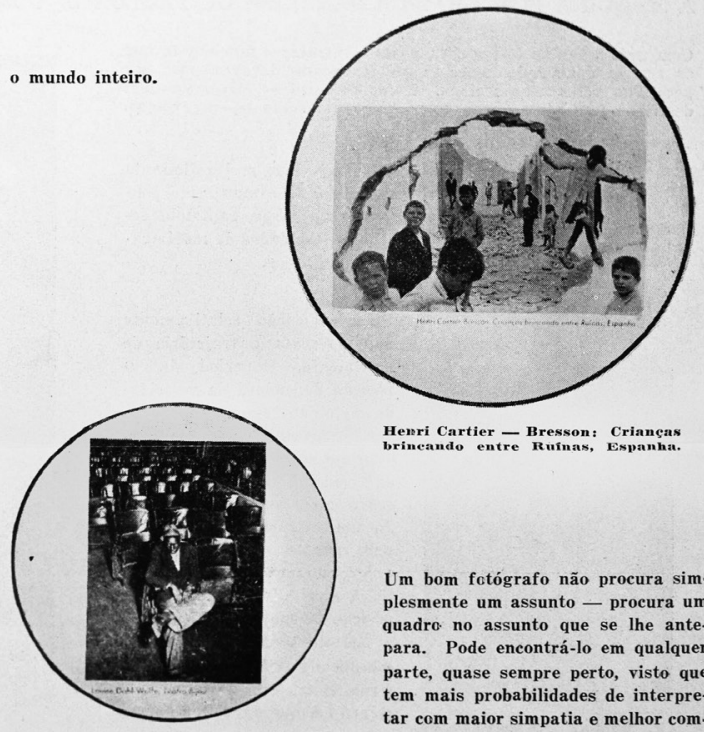

Louise Dahl - Wolfe: Teatro Bijou

Um bom fotógrafo não procura simplesmente um assunto - procura um quadre no assunto que se lhe antepara. Pode encontrá-lo em qualque parte, quase sempre perto, visto que tem mais probabilidades de interpretar com maior simpatia e melhor compreensão aquilo que melhor conhece.

Figura 5 - Escolhe o seu assunto. Quinto painel da exposição Fotografia Artística, Biblioteca Municipal de São Paulo, 1947. Íris, São Paulo, n.6, jun. 1947. Biblioteca da Cinemateca Brasileira, MinC, São Paulo.

COMPÕE COM A SUA MÁQUINA FOTOGRÁFICA

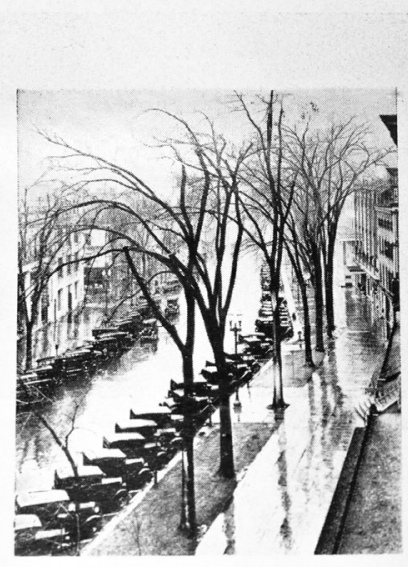

Walker Evans: Rua Prineipal, Os assuntos mais comuns podem tornar-se quadros notávèis nas mãos de um
fotógrafo que sabe planejar as suas composiçóes no visor de sua máquina.

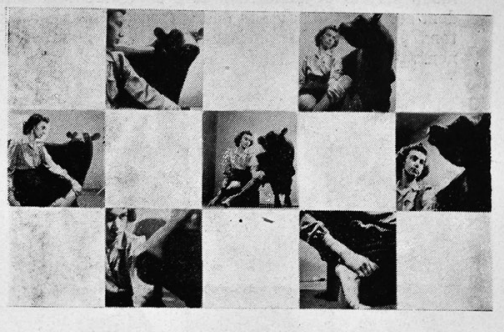

Fotografias cedidas por Standard oil Company de

o desenho de uma fotografia depende em grande parte da posição da máquina fotográfica em relação ao assunto. É possível alterar completamente uma fotografia movendo a máquina alguns decímetros para a direita ou para a esquerda, para cima ou para baixo, para mais perto ou para mais longe daquilo que se deseja fotografar.

Figura 6 - Compõe com sua máquina fotográfica. Sexto painel da exposição Fotografia Artística, Biblioteca Municipal de São Paulo, 1947. Íris, São Paulo, n.6, jun. 1947. Biblioteca da Cinemateca Brasileira, MinC, São Paulo. 


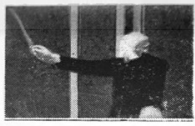

Em qualquer fotografia de motivos em movimento, particularmente de gente, o fotógrafo precisa decidir em que instante deverá manobrar o obturador. A demora de uma fração de um segundo conhecer as alteracóes na pose e expressão à medida que vão tendo lugar e agir ràpidamente de acôrdo com as mesmas.
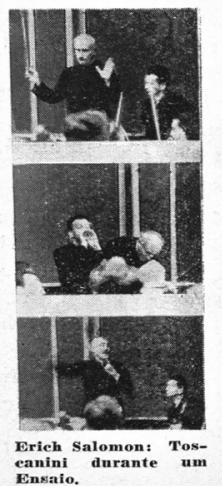

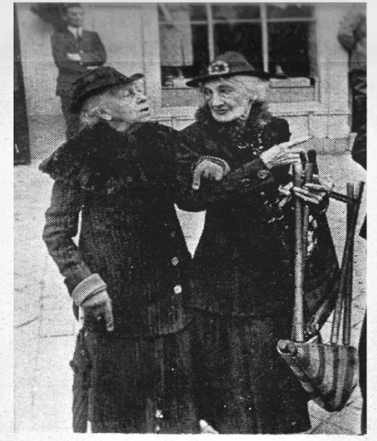

Henri Cartier: Mulher
uma parada em Paris.

Ao tomar uma fotografia de pessoas sem pose o fotógrafo fica às vêzes à mercê da orte, porém se conseguir captar o momento que deseja, a fotografia será provàvelmente interessante - pois o aparelho foerminado mode captar o drama de um demente impossível a qualquer outro processo artístico. Não há, contudo, razão para que o fotógrafo dependa inteiramente da sorte. Deve focalizar a sua máquina, fixar a velocidade da objetiva, e a abertura do diafragma antecipadamente, preparando-se quando êste chegar.

Figura 7 - Escolhe o momento. Sétimo painel da exposição Fotografia Artística, Biblioteca Municipal de São Paulo, 1947. Íris, São Paulo, n.6, jun. 1947. Biblioteca da Cinemateca Brasileira, MinC, São Paulo.

A MAQUINA FOTOGRÁFICA REPRODUZ DETALHES INFINITOS
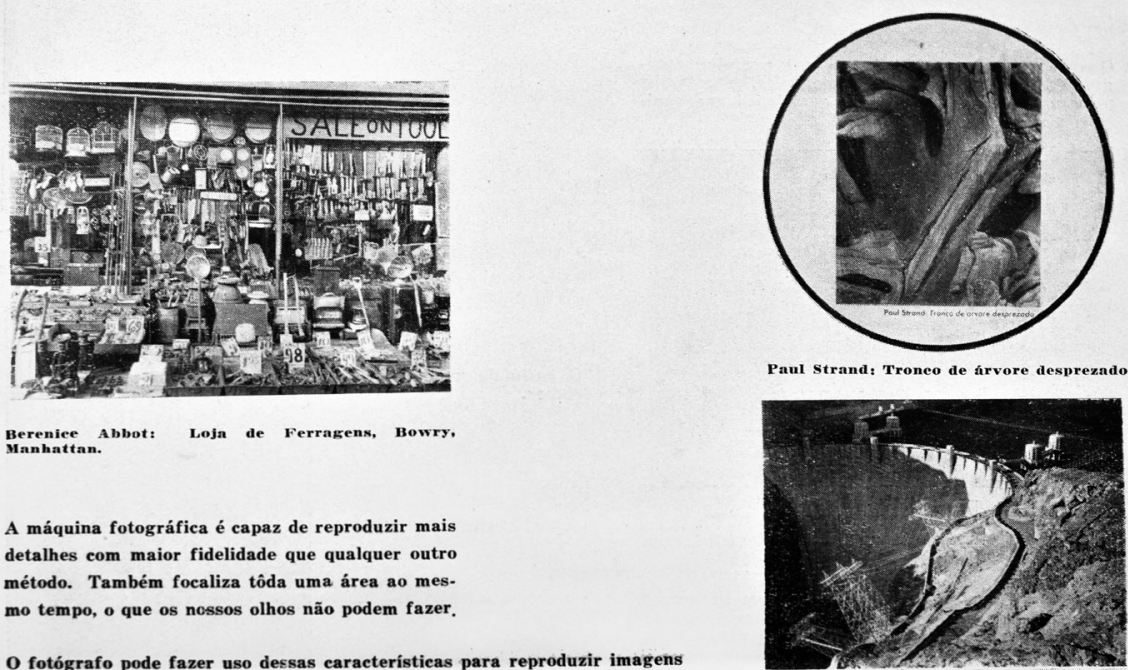

A máquina fotográfica é capaz de reproduzir mais detalhes com maior fidelidade que qualquer outro método. Também focaliza tôda uma área ao mes. mo tempo, o que os nossos olhos não podem fazer.

O fotógrafo pode fazer uso dessas características para reproduzir imagens brilhantes, quase super-realistas, e - a pouca distâneia - tornar-nos eoneientes da estrutura, contestura e desenho em têrmos novos.

Figura 8 - A máquina fotográfica reproduz detalhes infinitos. Oitavo painel da exposição Fotografia Artística, Biblioteca Municipal de São Paulo, 1947. Íris, São Paulo, n.6, jun. 1947. Biblioteca da Cinemateca Brasileira, MinC, São Paulo. 

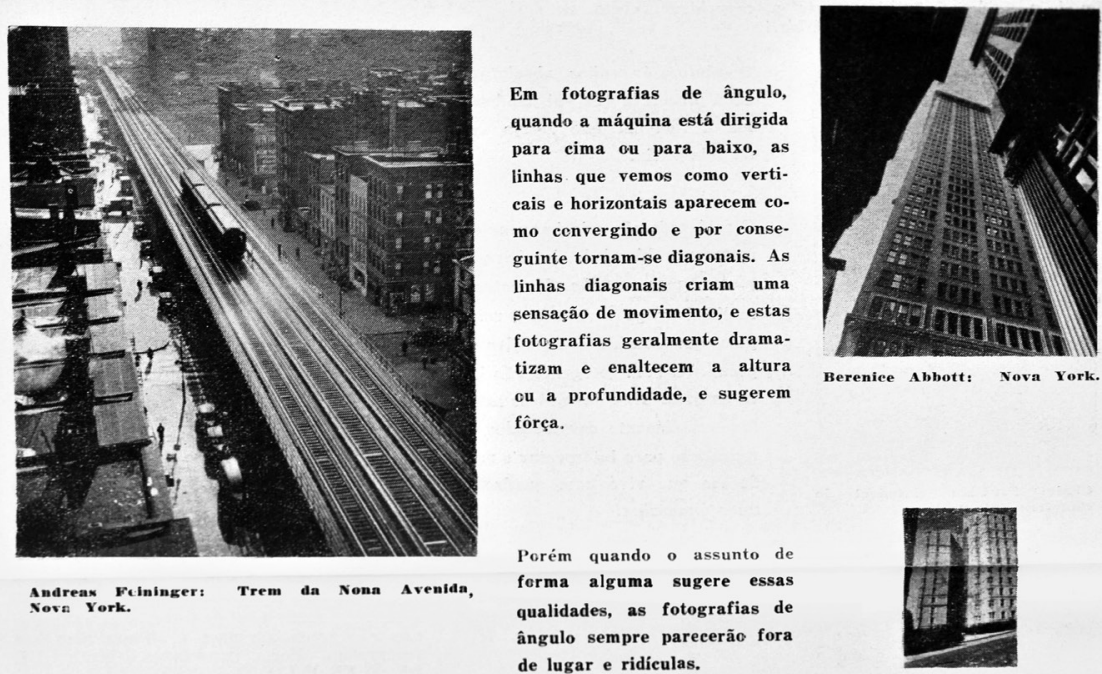

Berenice Abbott: Nova York.

Sovin York. de lugar e ridiculas.

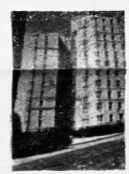

Figura 9 - A máquina fotográfica cria a sua própria perspectiva. Nono painel da exposição Fotografia Artística, Biblioteca Municipal de São Paulo, 1947. Íris, São Paulo, n.6, jun. 1947. Biblioteca da Cinemateca Brasileira, MinC, São Paulo.

A MAQUINA FOTOGRÁFICA COMPRIME OU AMPLIA O ESPAÇO

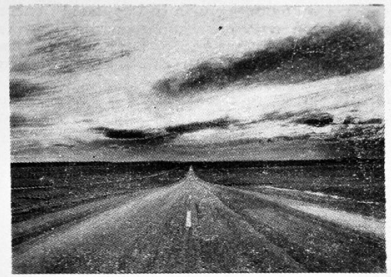

Arthur Rothstein: Rodovia Federal $\mathbf{N}$. 3o, wyoming.

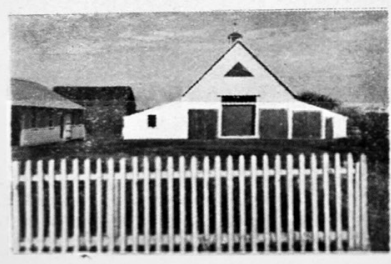

Amel Adama, Cerea de Eatíbulo, Cabo Cod
A capacidade para alterar o tamanho relative e a clareza dos objetos du ao fotógrafo um domínio sôbre a ilusão do espaço de três dimensões.

A máquina pode ser usada para par uma kensação de distância infinita e espaço amplo e profundo tornando o primeiro plano maior e mais claro que o plano posterior.

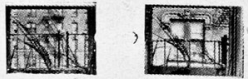

Ou pode limitar a sensação do espaço e trazer tudo a um plano frontal de pouca profundidade, afazendo o primeiro plano e o plano do fundo relativamente semelhantes em tamanho e clareza.

o tamanho relativo do primeire plano e do plano do fundo é controlado aquí pela extensão focal da lente e a posição da máquina.

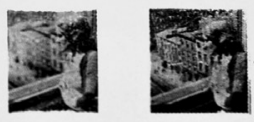

A profundidade e a clareza sáo controladas 
A MÁQUINA FOTOGRÁFICA PARALISA OU PROLONGA O MOVIMENTO

Com uma máquina fotográfica pode-se retratar o movimento que se realiza demasiado depressa ou demasiado devagar para ser desenhos fantásticos, mas estes são reais como os que vemos.

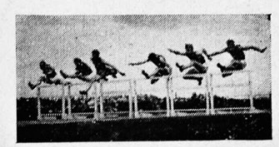

Corrida de Obstáculos (fotogratin cedida por Ewing
Galloway)

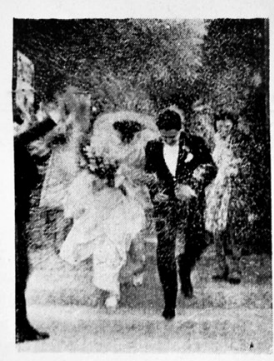

ก. Martin
Uma exposição muito diminuta congela a ação num certo ponto do seu curso, captando desenhos destacados de movimen. tos paralizados.

Uma exposição relativamente longa retrata a trajetória do longa retrata a trajetoria do posica dependeŕ da va exposicno dependera da velocidade do injeto en movimento das intençбes do fotografo. Assim, por exemplo, a fotografia da cerimônia de casamento recebeu uma exposição de $1 / 28$ de um segundo, o suficiente para captar o movimento do arroz, enquanto que a fotografia à direita recebeu uma exposicão de mais de um minuto a fim de retratar 0 desenhe a fin de retratar o desenho complicado feito por una lanterna elétrica portátil no momento em que dá voltas no ar.

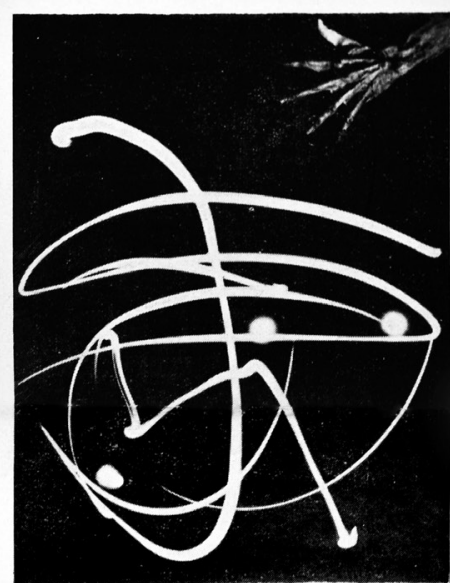

Barbara Morgan: Desenho Luminoso.

Figura 11 - A máquina fotográfica paralisa ou prolonga o movimento. Décimo primeiro painel da exposição Fotografia Artística, Biblioteca Municipal de São Paulo, 1947. Íris, São Paulo, n.6, jun. 1947. Biblioteca da Cinemateca Brasileira, MinC, São Paulo.

A MÁQUINA FOTOGRÁFICA TRADUZ AS CÔRES EM BRANCO E NEGRO

As côres, que tanta importância têm em tudo o que vemos, têmco e negro. pletamente da sua significação normal, ainda conservem um sentido fotográfico, pois cada côr pode a corecer mais ténue ou mais escura, edessa forma as côres que de outro modo seriam reproduzidas com o mesmo tom einzento, podem ser separadas umas das outras em tonalidades. Alguns tons podem receber ênfase
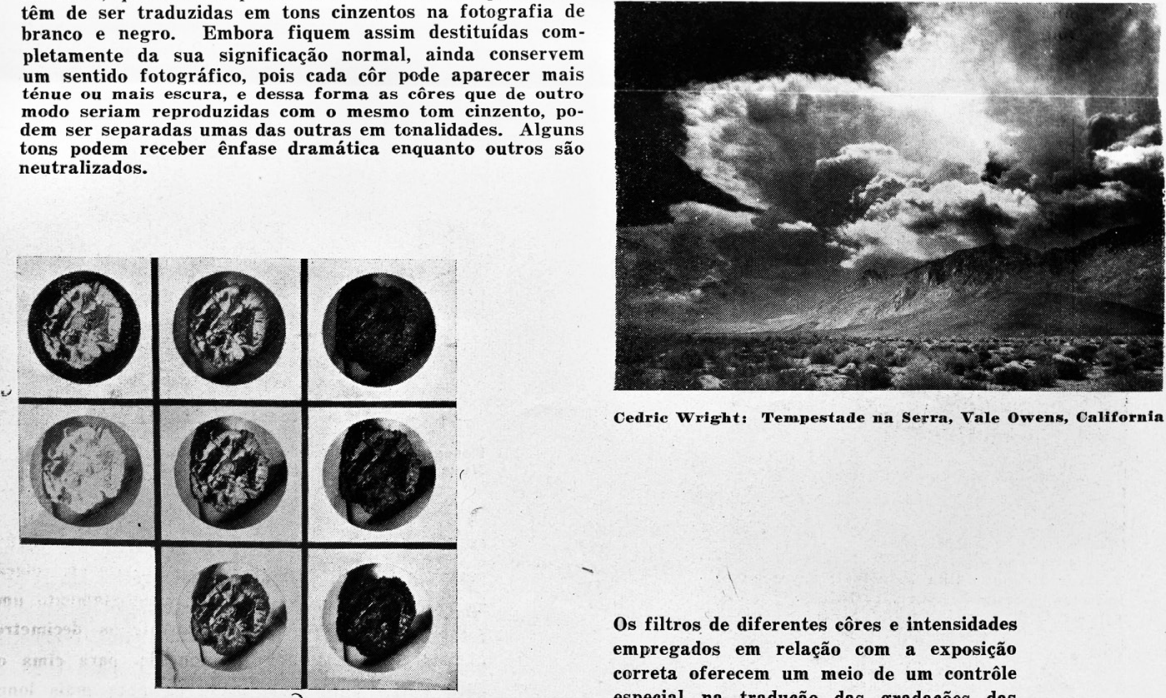

Cedric Wright: Tempestade na Serra, Vale Owens, California

Fotografias por Andreas Feininger. Os filtros de diferentes côres e intensidade correta of erecem um meio de um contrôle especial na tradução das gradações das côres para o branco e negro.

Figura 12 - A máquina fotográfica traduz as cores em branco e negro. Décimo segundo painel da exposição Fotografia Artística, Biblioteca Municipal de São Paulo, 1947. Íris, São Paulo, n.6, jun. 1947. Biblioteca da Cinemateca Brasileira, MinC, São Paulo. 
29. A lista de fotógrafos participantes da exposição publicada na revista Íris incluiu, por engano, o nome de Chaim Soutine, pintor expressionista (1893-1943), que teve uma pintura com o tema da Catedral de Chartres reproduzida no segundo painel, a fim de permitir a sua comparação com uma foto de Charles Sheeler do mesmo monumento. Observa-se, por outro lado, que o nome de R. Martin não consta na lista da revista Iris.

30. Essa imagem integrava os arquivos da George Eastman House, a Kodak, tendo sido enviada para participar de um dos concursos de fotografia promovido pela companhia destinado a fotógrafos amadores. Nos arquivos do museu não constam informações sobre o autor, embora a imagem esteja reproduzida no catálogo da exposição. Para uma análise da exposição The American Snapshot ver Ariane Pollet (2012, p.132-134).

31. Nascidos nos EUA: Ansel Adams, Charles Sheeler, Edward Weston, Paul Strand, Berenice Abbott; Arthur Rothstein, Barbara Morgan, Cedric Wright, Helen Lewitt, Louise Dahl-Wolfe, Ralph Steiner, Walker Evans e Wayne Miller; imigrante naturalizado residente nos EUA: Andreas Feininger; europeus: Erich Salomon e Henri Cartier-Bresson.

32. Ver Annateresa Fabris (2012). Cabe fazer a distinção entre Straight Photography e fotografia direta. A primeira refere-se ao movimento de vanguarda norte-americano que teve entre seus adeptos Alfred Stieglitz e Paul Strand e defendia o uso da fotografia sem intervenções nos negativos e nas cópias fotográficas. Já o termo fotografia direta refere-se ao mesmo tipo de uso, porém não vinculado necessariamente ao movimento norte-americano.
1. Fotografia Artística;

2. O fotógrafo é um artista;

3. Trabalha com um aparelho mecânico;

4. O seu meio de expressão é uma escala de valores;

5. Escolhe o seu assunto;

6. Compõe com sua máquina fotográfica;

7. Escolhe o momento;

8. A máquina fotográfica reproduz detalhes infinitos;

9. A máquina fotográfica cria sua própria perspectiva;

10. A máquina fotográfica comprime ou amplia o espaço;

11. A máquina fotográfica paralisa ou prolonga o movimento;

12. A máquina fotográfica traduz as cores em branco e negro.

Os painéis da exposição estavam organizados, portanto, em torno de três grandes eixos temáticos: o caráter artístico da fotografia (painel 1), o fotógrafo e as especificidades de seu trabalho (painéis $2,3,4,5,6$ e 7) e a câmera fotográfica e suas potencialidades (painéis $8,9,10,11$ e 12). Cada um desses eixos contava com fotografias e textos explicativos sobre os temas específicos indicados nos tífulos, contabilizando um total de 47 fotos. Dessas, 26 eram de autoria de 18 fotógrafos creditados, listados a seguir na ordem em que apareciam na exposição: Helen Lewitt, Ansel Adams, Ralph Steiner, Wayne Miller, Charles Sheeler, Andreas Feininger, Arthur Rothstein, Edward Weston, Henri Cartier-Bresson, Louise Dahl-Wolfe, Walker Evans, Erich Salomon, Berenice Abbott, Paul Strand, Edward Weston, Arthur Rothstein, R. Martin, Barbara Morgan e Cedric Wright29. Dentre eles apenas R. Martin não era um profissional conhecido, mas sim autor de uma foto de casamento selecionada para a exposição The American Snapshot realizada no MoMA entre março e abril de $1944^{30}$.

A maioria dos fotógrafos aparece na exposição com apenas uma imagem, exceto Andreas Feininger, Ansel Adams, Berenice Abbott e CartierBresson, com duas fotos cada, e Eric Salomon com quatro pequenas fotos sequenciais. Uma avaliação da lista dos 17 fotógrafos da exposição por nacionalidade, tirando R. Martin, indica que 13 nasceram nos Estados Unidos, um era imigrante naturalizado e dois eram europeus, sendo um alemão e um francês ${ }^{31}$. Já do ponto de vista da temática, das 26 fotos dos autores citados, 11 enfocam o elemento humano, 11 apresentam cenas urbanas, paisagens, estruturas arquitetônicas ou industriais e quatro ressaltam elementos gráficos próximos do desenho e da abstração. Annateresa Fabris avalia que a especificidade do meio fotográfico e a opção pela fotografia direta são características comuns a todas as fotos e, segundo ela, é possível identificar também algumas vertentes às quais estariam filiadas: à Straight Photography, ao fotojornalismo e à documentação de matriz realista ${ }^{32}$. Não podemos deixar de lembrar a presença da fotografia amadora na exposição. Mesmo que pontual, ela tem um papel estratégico como veremos adiante. 
Os painéis traziam ainda 21 fotos de tamanho reduzido, nem sempre creditadas, que visavam ilustrar diferentes aspectos da técnica fotográfica. Um bom exemplo desse uso pode ser encontrado no 1 1 painel, em que foram incluídas oito pequenas imagens produzidas por Feininger, com a utilização de diferentes filtros, especialmente para demonstrar os efeitos que se pode obter por meio deste tipo de recurso ${ }^{33}$. Outra fotografia ilustrativa, cedida por uma agência, trazia atletas saltando obstáculos e foi utilizada no 10 painel para demonstrar a capacidade da fotografia de congelar o movimento ${ }^{34}$. Cabe mencionar ainda, por seu caráter inusitado, sete pequenas fotos de uma mulher em diferentes poses junto a um bezerro, que visavam demonstrar as inúmeras possibilidades de composição permitidas pela fotografia. As imagens foram cedidas pela Standard Oil Company de New Jersey, empresa de petróleo pertencente à família Rockefeller.

Em que pese a força visual de muitas das fotografias presentes na exposição, dada por seus conteúdos e/ou características formais, o sentido geral era construído por meio da relação entre texto e imagem, sendo que o texto prevalecia sobre a informação visual. A apreciação das fotografias, por parte do observador, era direcionada pelas frases assertivas que davam título aos painéis e pelas mensagens instrutivas que as acompanhavam, como os exemplos que se seguem:

A máquina fotográfica é um aparelho de grandes possibilidades, porém, o fotógrafo, como qualquer outro artista, é mais importante que os instrumentos por ele usados. (Painel 1)

O fotógrafo não imita as qualidades das outras artes; faz uso somente dos métodos fotográficos para interpretar o mundo em que vive num quadro de duas dimensões. (Painel 3)

Ao tomar uma fotografia de pessoas sem pose o fotógrafo fica às vezes à mercê da sorte, porém, se conseguir captar o movimento que deseja, a fotografia será provavelmente interessante - pois o aparelho fotográfico pode captar o drama de um determinado momento de uma forma inteiramente impossível a qualquer outro processo artístico. (Painel 7)

Os painéis traziam apenas esse tipo de texto, juntamente com as legendas das fotos com o nome dos fotógrafos e o título das fotografias. Não havia menção a datas. No que diz respeito à distribuição de textos e imagens, os painéis da exposição assemelhavam-se às páginas de um livro ilustrado e demandavam uma leitura atenta para que todas as instruções pudessem ser bem assimiladas. $\bigcirc$ design dos painéis variava de acordo com o número de fotografias e a extensão dos textos que deviam abrigar. Isso acarretava uma grande variação no tamanho das fotografias expostas e certamente influenciou a avaliação do público pela importância relativa de cada uma delas ${ }^{35}$.

Se compararmos o conteúdo dos painéis originais, apresentados no MoMA, com a versão da exposição em português, enviada ao Brasil, constataremos apenas duas pequenas modificações ${ }^{36}$. A primeira delas foi a substituição de uma
33. Segundo o release do MoMA, Feininger produziu as imagens que ilustram os procedimentos técnicos especialmente para a mostra.

34. Consta neste painel que o responsável pela cessão desta foto foi Erwing Galloway. Jornalista e editor de fotografia, Galloway era também dono de uma agência de fotografia em Nova York que levava o seu nome. Disponível em: <http:// library.syr.edu/digital/ guides/g/galloway_e.htm> acesso em 01/05/2014

35. De posse do tamanho original dos painéis, podemos calcular o tamanho das reproduções fotográficas apresentadas. A foto de $\mathrm{He}$ len Levitt, por exemplo, que era a maior de todas as imagens, media cerca de $17 \mathrm{~cm}$ x $26 \mathrm{~cm}$; ao passo que a foto do grupo de crianças na Espanha, de autoria de Cartier-Bresson, media cerca de 7 $\mathrm{cm} \times 11 \mathrm{~cm}$.

36. Os títulos dos painéis originais eram: I.Creative photography; II.The photographer is an artist; III.He works with a mechanical tool; IV.His medium is a scale of values; V. He selects the subject; VI. He composes with camera; VII. He selects the moment; VIII.The camera records infinite detail; $I X$. The camera creates its own perspective; X.The camera compresses or extends space, $X I$ The camera stops or prolongs motion; XII.The camera translates color into black and white. Cf. Folder de divulgação. The Museum of Modern Art Archives, NY, CE II.1.49.1.1. A tese de doutorado de Diana Dobranszky (2008, v.2, p. 162 165) traz uma descrição detalhada da exposição que utilizamos como base para a comparação entre a exposição original e a versão em português. 
37. Em sua tese de doutorado, Diana Dobranszky analisa matérias escritas por Mabel Scacheri para o jornal Word-Telegram em que a jornalista aponta a falta de pertinência de algumas das imagens apresentadas em relação aos objetivos da exposição. A fotografia de Weegee, em particular, foi considerada um mau exemplo por não se adequar, segundo Scacheri, ao tema do painel no qual havia sido incluída. Ver Diana Dobranszky (2008, p. 157158).

38. Embora não conste nos créditos, há no orçamento da exposição a discriminação do pagamento de U\$ 200 a Feininger pelo serviço de designer. Cf. The Museum of Modern Art Archives, NY, CE II.1.49.1.

39. A Fundação Juan March organizou em 2008 uma grande retrospectiva do trabalho do fotógrafo, intitulada "Andreas Feininger, 1906-1999”, que resultou em um catálogo, de mesmo nome, no qual se encontra uma biografia de Feininger, da qual retiramos os dados aqui apresentados. Inclui ainda diversos textos teóricos sobre a sua produção fotográfica, além de grande quantidade de imagens. Ver: Fundación Juan March (2008).

40. Podemos citar duas matérias assinadas por Feininger, publicadas na revista Life, que se enquadram neste perfil: Pest Portraits (1950) e Skull, Ribs Act as Armor (1952). A primeira apresenta macro fotografias de insetos e a segunda imagens em raio-X.

41. No ano de sua morte, em 1999, Feininger contava com mais de 50 livros publicados, traduzidos em diversos idiomas, segundo o levantamento incluído no catálogo da exposição realizada pela Fundación Juan March. Dentre eles, pode- fotografia de Weegee (Opening night at the Opera), locada no sétimo painel, por uma foto de Cartier-Bresson (Mulheres assistinido a uma parada em Paris). A supressão da fotografia de Weegee parece ter sido resultado de críticas à sua inclusão na mostra quando esta foi apresentada no $\mathrm{MoMA}^{37}$. A segunda modificação foi a retirada de uma das duas fotos ilustrativas situadas no nono painel. Essas mudanças foram pontuais e não chegaram a modificar o conteúdo da exposição, muito menos o seu conceito geral. No entanto, a troca do título merece ser melhor investigada, pois, Fotografia Criativa era um conceito que vinha sendo desenvolvido por Andreas Feininger, assunto que trataremos a seguir.

\section{C conceito de fotografia criativa de Andreas Feininger}

A exposição Fotografia Artística não pode ser bem compreendida sem levarmos em consideração a concepção de fotografia de Andreas Feininger, fotógrafo convidado pelo MoMA como consultor técnico da mostra original e que veio a ser também o responsável pelo design dos painéis ${ }^{38}$.

Nascido em Paris, em 1906, Andreas Feininger era o primogênito do pintor Leonel Feininger e ainda criança mudou-se com a família para a Alemanha ${ }^{39}$. Feininger estudou marcenaria na Bauhaus, onde seu pai era professor, período durante o qual assistiv algumas aulas de fotografia ministradas por Walter Peterhans. Mais tarde formou-se arquiteto pela Escola Estatal de Arquitetura de Weimar e na mesma época iniciou suas atividades como fotógrafo. Em 1932 trabalhou durante alguns meses no estúdio de Le Corbusier em Paris, porém logo se viu obrigado a mudar-se para Estocolmo, por conta de problemas com o seu visto de permanência na França, passando a atuar como fotógrafo de arquitetura. Dificuldades profissionais e pessoais, decorrentes de sua origem judaica, fizeram com que Feininger emigrasse para Nova York em 1939. Depois de trabalhar para a agência de fotografia Black Star, colaborou com a revista Life como free-lancer até ser contratado em 1943.

Ao longo dos 19 anos em que permaneceu na Life, Andreas Feininger usufruiu de ótimas condições de trabalho. Paralelamente à produção de fotorreportagens, cujos temas frequentemente ele próprio sugeria, desenvolveu experimentações diversas que podiam envolver desde a construção de câmeras fotográficas para a obtenção de certos resultados pouco usuais, até o uso de técnicas como cronofotografia, raio-x, micro e macro fotografia, entre outras ${ }^{40}$. Foi também na revista que ele teve oportunidade de dar prosseguimento à sua produção como escritor, iniciada anos antes quando ainda residia na Europa. Feininger on photography, escrito por sugestão do editor da Life e desenvolvido com o apoio da revista, obteve grande repercussão e estimulou o autor a continuar investindo na escrita e organização de livros de fotografia ao longo de toda sua trajetória profissional| $^{41}$

O convite oficial do MoMA endereçado a Andreas Feininger para que participasse da exposição Fotografia Criativa data de abril de 194442. A 
correspondência menciona a mostra Funções da Câmera, organizada no museu dois anos antes, com a colaboração do próprio Feininger, e afirma que o novo projeto seria uma espécie de desdobramento do anterior, com um número maior de imagens e maior ambição em seu escopo. Afirma ainda que a equipe do museu, encarregada do projeto, considerava que a mostra poderia atender aos mesmos propósitos do seu livro Fotografische Gestaltung. Publicado por Feininger na Alemanha, em 1935, Fotografische Gestaltung era um manual que explorava de maneira didática as inúmeras possibilidades técnicas da fotografia.

Não foi possível determinar como se deu a distribuição de tarefas e responsabilidades entre a equipe do MoMA e Andreas Feininger na realização da exposição. No entanto, um documento interno do museu, datado de 15 de março de 1944, apresenta uma sugestão de tópicos a serem abordados e recomenda que caso Feininger viesse mesmo a ser confirmado como consultor da mostra, fosse logo contatado antes que a equipe avançasse mais no projeto. Os tópicos sugeridos constam como sendo a especificação "das qualidades que qualquer fotógrafo pode alcançar", a saber: nitidez; desfoque; composição em claro e escuro; distorção de perspectiva; close-up; distância; ação congelada e ação prolongada. Há ainda a sugestão de três possíveis títulos para a exposição: Funções da câmera, $\bigcirc$ que a câmera é capaz de fazer e A arte da fotografia. $\bigcirc$ documento termina afirmando que todos os tópicos devem ser abordados no nível de entendimento do amador e que a mostra deve deixar claro que o bom fotógrafo é aquele para quem não importa o quão limitados sejam os seus meios técnicos, já que ele sabe o efeito que procura e como obtê-lo ${ }^{43}$. Constata-se, assim, que a equipe do museu tinha uma conceituação prévia da exposição, muito embora ela fosse totalmente calcada nas ideias do próprio Feininger.

É possível afirmar que o embrião do conceito de Fotografia Criativa aparece desde as primeiras publicações de Andreas Feininger, no entanto, ele iria sistematizá-lo um pouco mais tarde em um livro intitulado The creative photographer publicado em 1955. Para o autor a fotografia podia ser classificada em três grandes categorias: utilitária, documental e criativa ${ }^{44}$. A primeira teria como principal objetivo registrar, a segunda informar e educar e a terceira teria o papel de estimular e inspirar:

Em contraste com a fotografia documental que é basicamente descritiva, lidando com fatos e eventos específicos, a fotografia criativa é interpretativa e simbólica. $\bigcirc$ seu objetivo é passar uma atmosfera, um sentimento, uma ideia. Na fotografia criativa o assunto geralmente não é mais do que um veículo que carrega a ideia que o fotógrafo quer expressar ${ }^{45}$.

Ainda de acordo com o fotógrafo aqueles que trabalhavam no campo da fotografia criativa eram artistas, o que justificaria a realização de mostras dos adeptos dessa modalidade de expressão no Museu de Arte Moderna de Nova York:

Os fotógrafos criativos são artistas independentes. Eles são imaginativos, observadores e frequentemente opinativos. Eles são interessados no seu entorno, nas pessoas e em determinados assuntos sobre os quais eles têm opiniões fortes. (...) $\bigcirc$ assunto e o significado mos citar: New paths in photography (1939); New York (1945); Feininger on photography (1949); The anatomy of nature (1956); The world trough my eyes (1963); Principles of composition in photography (1973) e Nature in miniature (1989). Alguns deles alcançaram grandes tiragens, permitindo uma ampla difusão de suas ideias e de sua produção fotográfica a partir de meados da década de 1940. Ver Fundación Juan March (2008).

42. Cf. The Museum of Modern Art Archives, NY, CE II.1.49.1

43. Memorando interno encaminhado por Alice Otis (Supervisor of Educational Service) para a diretora do Departamento de Exposições Itinerantes, Elodie Couter. Cf. The Museum of Modern Art Archives, NY, CE II.1.49.1

44. Ver Andreas Feininger (1955), p. 16.

45. Idem, p.18. Tradução da autora. 
46. Feininger qualifica os adeptos da fotografia criativa como: "(...) poor photo technicians". Cf. Andreas Feininger (1955, p.133-134). Tradução da autora.

47. Ver Andreas Feininger. In: New paths in photography. Apud Jean-François Chevrier (2008, p.51).

48. A revista Íris foi lançada em janeiro de 1947 e, segundo Camargo e Mendes, "Constitui a primeira publicação de porte com circulação comercial, não vinculada a fotoclubes ou mesmo varejistas". Na comissão técnica da revista estavam Thomaz Farkas e Benedito J. Duarte. Já o Foto-Cine Clube Bandeirante Boletim surgiu em maio de 1946, com circulação restrita, destinada inicialmente apenas aos associados do Clube que o recebiam gratuitamente. Ver Monica Junqueira Camargo e Ricardo Mendes (1992, p. 80-82). de suas fotos são o seu único interesse. Eles nunca se importam com o tipo de equipamento que usam e muitas vezes são pobres do ponto de vista da técnica fotográfica. Mas apesar disso, suas fotografias têm tal importância que são exibidas no Museu de Arte Moderna de Nova York. A maioria dos fotógrafos criativos expressam e interpretam os eventos, ideias e problemas do seu tempo. Olhando para as suas fotos as pessoas, por identificação, podem ver a si mesmas e os problemas do seu tempo sob uma nova luz ${ }^{46}$.

A descrição de Feininger nos permite elencar as principais características do que ele entendia por fotografia criativa. Tratava-se de um tipo de imagem que buscava oferecer uma interpretação visual acerca das cenas ou dos acontecimentos contemporâneos, tinha caráter simbólico, tomava as situações particulares como indicativas de um contexto maior e, em função de seus temas e abordagens, revelava frequentemente preocupação com a dimensão humana dos fałos. Segundo Feininger, o primeiro passo rumo à fotografia criativa era enfatizar as características gráficas da imagem fotográfica, tanto naquelas de cunho figurativo, quanto nas abstratas $^{47}$. Ele ressalta ainda que os adeptos dessa tendência não eram necessariamente exímios na técnica fotográfica.

$\bigcirc$ conceito de fotografia criativa libertava a fotografia dos rótulos de estilos, escolas ou tendências e funcionava, em última instância, como um amplo guarda-chuva que possibilitava abarcar as mais diversas experiências, não só da fotografia de vanguarda como também do fotojornalismo, da fotografia moderna e até mesmo da foto amadora.

\section{A divulgação e a recepção da exposição Fotografia Artística}

A investigação das estratégias de divulgação da exposição Fotografia Artística no Brasil pode ajudar-nos a compreender os objetivos que fizerem com que fosse trazida a São Paulo, ao passo que o estudo de sua recepção nos servirá para desvendar aspectos importantes da discussão local acerca da chamada fotografia artística. Para tanto iremos contrapor a divulgação da mostra realizada pela revista Íris e sua recepção pelo Foto Cine Clube Bandeirante-Boletim, órgão oficial do Foto Cine Clube Bandeirante ${ }^{48}$.

A revista Íris, única publicação comercial dedicada à fotografia no país na época da realização da mostra Fotografia Artística, fez uma chamada prévia para o evento e lançou uma edição especial dedicada aos Estados Unidos no período da exposição, como vimos anteriormente. Além da reprodução dos painéis, a revista publicou também diversos textos que se caracterizavam pela exaltação da supremacia dos Estados Unidos na área de produção de imagens, a começar pelo editorial que ressaltava a suposta influência da fotografia norte-americana no Brasil:

Dedicando esta edição da Íris aos Estados Unidos da América do Norte, seria muito justificado que nos ocupássemos por uma forma toda especial da influência que a fotografia norte-americana exerce sobre a fotografia nacional. E essa influência é tão evidente e tão interessante que estamos certos de que os nossos leitores concordarão com nosso ponto de 
vista. Se a fotografia teve seu berço em outra parte, foi contudo na América que efetivamente encontrou o campo mais propício para o seu desenvolvimento (...) Sendo a fotografia uma linguagem universal, e sendo as nossas inclinações tão semelhantes às dos nossos amigos do norte, é perfeitamente compreensível que ocorra toda essa nossa receptividade ao expressionismo fotográfico ${ }^{49}$

$\bigcirc$ texto não cita exemplos da produção em que a referida influência poderia ser verificada, deixando em aberto a qual segmento da fotografia nacional o autor se referia. Do mesmo modo, não são apontadas as características especificamente norte-americanas que poderiam ser identificadas na "fotografia nacional"50. Pelo enfoque geral dos textos, no entanto, não era a fotografia propriamente dita que a Íris buscava exaltar. Não só o editorial, mas toda aquela edição tinha um forte tom de propaganda, seja na capa, que apresentava uma vista aérea da Estátua da Liberdade, seja nos textos que faziam referência ao panamericanismo e à atuação do OCIAA. Mesmo já tendo passado algum tempo desde o fim da Política da Boa Vizinhança, devemos lembrar que a exposição fora preparada durante a sua vigência, entre 1943 e 1944, e que quase todos os textos haviam sido publicados originalmente nos Estados Unidos e traduzidos para o português. Naquele período o MoMA havia aderido ao esforço de guerra e a maioria de suas ações estava voltada para a propaganda política, visando colaborar com o governo norte-americano ${ }^{51}$. Na maioria dos artigos da ĺris, os autores se valem da fotografia e do cinema norte-americanos para lançar elogios à política dos Estados Unidos e defender a pertinência das ações daquele país durante a Segunda Guerra Mundial:

Bem mais eficientes que os relatórios dos jornais foram as fotografias dos feitos militares dos Estados Unidos na guerra. Estas fotografias foram expostas em vitrinas de estabelecimentos comerciais em todas as cidades americanas ou de países aliados, evidenciando aos olhos do mundo a coragem e a intrepidez do povo americano ${ }^{52}$.

teor e o tipo de linguagem dos textos da edição especial da revista Íris sobre os Estados Unidos nos leva a considerá-la como uma peça de propaganda pró-americana. A exposição Fotografia Artística foi utilizada como pretexto para a veiculação de um discurso laudatório acerca da hegemonia norte-americana no pós-guerra nas mais diversas áreas. Embora a revista tenha reproduzido todos os painéis apresentados na Biblioteca Municipal de São Paulo, nenhum dos artigos abordou diretamente a exposição.

Para tentarmos dimensionar a recepção da exposição enviada pelo MoMA a São Paulo devemos considerar que as discussões acerca do estatuto artístico da fotografia, naquele momento no Brasil, estavam centradas no ambiente fotoclubista. No ano de 1947, em especial, a produção fotoclubista brasileira ainda estava fortemente marcada pelo ideário pictorialista que definia a fotografia artística praticada no país. A exceção ao pictorialismo reinante ficava por conta dos pioneiros da Escola Paulista - os fotógrafos José Yalenti, Thomaz Farkas, German Lorca e Geraldo de Barros -, que em meados da década de 1940 haviam
49. Cf. João Pires d'Ávila (1947, p. 10-11). D'Ávila era membro da Comissão Técnica da revista e publicou esse texto na seção "Fala o editor".

50. Da produção do período, pode-se apontar um diálogo direto entre o fotojornalismo praticado na revista $O$ Cruzeiro e o modelo de fotorreportagem difundido pela revista Life. Ver Helouise Costa (2012, p. 202 323).

51. Sobre as ações do MoMA durante o esforço de guerra ver Harriet Bee e Michelle Elligott (2004).

52. Cf. Frederico R. Geiringer (1947, p. 16) 
53. A classificação desses fotógrafos como pioneiros da fotografia moderna no Brasil foi proposta pela primeira vez por Helouise Costa e Renato Rodrigues da Silva (2004, p. 36-47).

54. Agradeço ao pesquisador Ricardo Mendes pelas informações fornecidas sobre o evento e ao Prof. Rubens Fernandes pela indicação e acesso a importantes fontes de pesquisa.

55. Palestras sobre cinema: "Relações entre o cinema e a pintura" por Lourival Gomes Machado; "Filmologia, uma nova ciência” por Luis Almeida Salles e "O cinema e a cor" por Benedito J. Duarte.

56. Valêncio de Barros foi pictorialista durante toda sua trajetória como fotógrafo, ao passo que Jacob Polacow iniciou-se como pictorialista e depois passou a desenvolver uma produção eclética com influência modernista. Frederico R. Geiringer (1947, p. 16-25) descreve o conteúdo das palestras e afirma que atraíram grande público.

57. As palestras foram publicadas na íntegra em três edições consecutivas do Foto-Cine Clube Bandeirante Boletim. Ver Jacob Polacow (1947a, b, c) e Valêncio Barros (1947a, b, c).

58. Compur. A "Exposição de Fotografias Artísticas" (1947, p.11)

59. No final do texto lê-se "Compur", que parece ser o pseudônimo de alguém que assina do mesmo modo textos publicados em outras edições do Boletim.

60. Cf. Compur (1947).

61. Idem. se voltado para uma produção de cunho modernista no âmbito do Foto Cine Clube Bandeirante $^{53}$.

Um ciclo de palestras, organizado pelo Foto Cine Clube Bandeirante, foi realizado no auditório da Biblioteca Municipal como evento complementar à mostra Fotografia Artística. Reunindo profissionais e críticos locais, incluiu dois encontros sobre fotografia e três sobre cinema. Os temas tratados são muito elucidativos do tipo de recepção que a exposição recebeu em São Paulo ${ }^{54}$. As palestras sobre fotografia foram "O pictorialismo na arte fotográfica" por Jacob Polacow e "A fotografia é uma arte?" por Valêncio de Barros, realizadas nos dias 04 e 17 de julho55. Os dois palestrantes eram fotógrafos associados do Foto Cine Clube Bandeirante e adeptos do pictorialismo, tema sobre o qual discorreram em suas apresentações ${ }^{56}$. Em ambas, os respectivos autores defenderam a fotografia como uma forma de expressão artística desde que vinculada à estética pictorialista ${ }^{57}$.

Este episódio aponta para a defasagem existente entre as fotografias apresentadas na exposição Fotografia Artística e sua recepção local, fenômeno que fica ainda mais evidente em um artigo publicado no Foto-Cine Clube Bandeirante Boletim ${ }^{58}$. $O$ texto, assinado sob pseudônimo, reclama do generoso espaço dedicado à mostra nos jornais em comparação com a divulgação do Salão Internacional de Arte Fotográfica do Clube, realizado anualmente na Galeria Prestes Maia ${ }^{59}$. Em seguida, o autor relata a grande expectativa criada no meio em torno da exposição na Biblioteca Municipal e a consequente decepção causada pelo material que viria a ser exposto:

Sim, porque o que fomos encontrar no saguão da Biblioteca não foram os apregoados 12 painéis com fotografias artísticas, mas 12 cartazes com legendas explicativas dos recursos da fotografia, ilustradas com vários trabalhos exemplificadores ${ }^{60}$.

A decepção teria sido causada, segundo o autor, pelo fato da publicidade ter anunciado a exposição como sendo composta "pelos maiores artistas da Europa e dos Estados Unidos" e "pelos mais famosos fotógrafos norteamericanos". Mais adiante ele iria aprofundar sua crítica, chegando ao ponto de renegar o valor artístico da maioria das imagens em exibição:

Mas, com exceção de duas ou três (por exemplo, "Trem da Nova Avenida" de Andreas Feininger e "Tempestade da Serra" de Cedric Wright) nem mesmo essas fotografias ilustrativas dos cartazes possuem qualquer valor artístico já que se destinam mais a demonstrar e exemplificar problemas técnicos da fotografia, como sejam profundidade de foco, emprego de filtros, ângulos, velocidades do obturador, perspectivas, etc. Que valor artístico poderia ter por exemplo "Loja de Ferragens" de Berenice Abbott, um amontoado de quinquilharias numa fotografia com luz de frente, chata, sem relevo ou aquele flagrante banal de esquálidas e esfomeadas crianças napolitanas durante a guerra, de Wyane Miller, ou ainda, "Crianças brincando entre ruínas" de Henri Cartier e outras mais? (...) até mesmo o principiante terá uma ideia muito pobre e falsa do que seja "fotografia artística" uma vez que essa é a legenda que encima o primeiro cartaz" 
Na segunda parte de seu texto, após a virulenta crítica sobre a exposição apresentada na Biblioteca Municipal de São Paulo, o autor anônimo tenta amenizar o tom do artigo, afirmando que apesar do mal-entendido causado pela divulgação a exposição tinha grande valor para o leigo que eventualmente quisesse aprender a fotografar:

Dificilmente poderemos encontrar, em qualquer manual fotográfico, em tão poucas palavras e tão bem expostos, conceitos tão elucidativos. Sob esse ponto de vista, portanto, a exposição tem inegável mérito e melhor cumpriria sua finalidade se fosse exposta e circulasse pelas nossas escolas, entidades e clubes artísticos e culturais, recreativos e esportivos, tanto da capital como do interior. Seria um meio prático e dos mais eficientes para fazer com que os milhares de pessoas que possuem máquinas fotográficas atentem melhor para os vários problemas e recursos da fotografia e o que poderão obter com o emprego inteligente de seu aparelho, com isso despertando, quiça, vocações que permanecem adormecidas e ignoradas. Aí fica, entretanto, a sugestão ${ }^{62}$.

É importante tentarmos nos reportar ao contexto de época para situarmos essa crítica, uma vez que os fotógrafos citados não gozavam do pleno reconhecimento que viriam a usufruir algumas décadas depois. Cartier-Bresson, por exemplo, teve sua primeira exposição individual em um museu de arte poucos meses antes, em janeiro de 1947, no MoMA. Somente na década seguinte teria o seu trabalho reconhecido por um museu em seu país de origem. A foto das crianças brincando entre ruínas, de sua autoria, curiosamente também havia sido mal recebida por uma crítica norte-americana por ocasião da mostra Creative Photography em 1945. Para Mabel Scacheri, do jornal World-Telegram, a referida fotografia era um mero registro, não sendo capaz de revelar nada a respeito do pensamento ou do sentimento do fotógrafo diante daquela trágica situação63. Lá como aqui, a produção dos fotógrafos apresentados na exposição ainda era motivo de polêmica no que diz respeito ao seu valor artístico.

A análise da divulgação e da recepção da mostra Fotografia Artística pela revista Íris e pelo Foto-Cine Clube Bandeirante Boletim, respectivamente, revela interesses políticos diversos que a princípio não eram explícitos, bem como conflitos entre diferentes concepções de fotografia que estavam em disputa no período do pós-guerra pela legitimação e consequente ocupação de espaços institucionais. $\bigcirc$ fato das duas publicações estarem diretamente vinculadas à vinda da exposição ao Brasil só reforça a complexidade de interesses dos grupos envolvidos, assim como a inexistência de um posicionamento comum a todos eles acerca do valor do conteúdo e dos objetivos do evento ${ }^{64}$.

Fotografia criativa $\times$ fotografia artística

Se os textos de Andreas Feininger mostravam claramente que fotografia criativa não era sinônimo de fotografia artística, podemos atribuir uma parte dos mal-entendidos que marcaram a recepção da exposição no Brasil à troca do título
62. Idem.

63. Cf. Mabel Scacheri, (1945, apud Diana Dobranszky, 2008, p.157).

64. No caso do Bandeirante, dada a reação de vários de seus membros, é possível supor que o Clube tenha apoiado a vinda da exposição em função do que era anunciado pelo MoMA, sem que os fotógrafos tivessem conhecimento de seu conteúdo específico. 
65. Não encontramos documentos que justifiquem a adaptação do título da exposição para o português que se deu da mesma forma na versão em espanhol. Nossa hipótese é que a troca do nome teria sido realizada com o intuito de se utilizar um termo mais abrangente, de uso corrente no ambiente local, e com maior potencial de atração do público de maneira geral.

66. Cf. Valêncio de Barros (1947c, p.5).

67. Outras referências indiretas à exposição aparecem nos itens listados por Valêncio de Barros em sua fala, uma vez que a escolha do assunto era tema do quinto painel da exposição, a fineza dos detalhes estava contemplada no oitavo painel e os caminhos para o aperfeiçoamento da técnica fotográfica foram descritos nos cinco painéis dedicados à câmera.

68. Ver Vanessa Lenzini, (2008, p.51-57).

69. Cf. Valêncio de Barros (1947c, p.5). na versão em português ${ }^{65}$. $\bigcirc$ conceito de fotografia artística, tal como empregado no âmbito do fotoclubismo paulista, estava muito distante do conceito de fotografia criativa de Feininger.

A distinção entre os dois conceitos pode ser melhor explicitada se retomarmos o conteúdo das palestras sobre fotografia realizadas durante a exposição na Biblioteca Municipal de São Paulo. Educadamente, tanto Jacob Polacow quanto Valêncio de Barros abstiveram-se de comentar a exposição e explicitar suas discordâncias em relação à atribuição do estatuto de arte às fotos apresentadas. Ao invés disso trataram de discorrer sobre os princípios do pictorialismo, base da concepção de fotografia artística compartilhada naquele momento pela maioria dos associados do Foto Cine Clube Bandeirante. $O$ desacordo materializou-se também na escolha das imagens apresentadas em suas respectivas palestras, uma vez que eles não recorreram às fotos da exposição, como era de se esperar. Mesmo assim, Barros chegou a fazer uma menção indireta à mostra:

(...) o público em geral não distingue uma fotografia executada com arte de uma fotografia artística. Admira na primeira a escolha feliz do assunto, a perfeição técnica, a fineza dos detalhes, a beleza da viragem, mas ignora que entre ela e a fotografia artística existe um mundo a percorrer. E que para percorrer essa distância, o fotógrafo precisa conhecer os preceitos da estéfica, que são os caminhos que conduzem à misteriosa fonte de beleza que é a arte ${ }^{66}$.

Por meio de um artifício retórico, o autor estabelece uma distinção entre fotografias artísticas e "fotografias executadas com arte", deixando implícito que para ele as imagens da exposição se filiavam à segunda categoria e não à primeira. Desse modo, ele reconhece a perícia dos fotógrafos estrangeiros presentes na mostra, porém, desqualifica suas fotos por não obedecerem aos preceitos estéticos defendidos pelo Bandeirante ${ }^{67}$. Vanessa Lenzini aprofunda a análise do debate estabelecido por Jacob Polacow e Valêncio de Barros. Ela chama atenção para o fato de que os argumentos de ambos levam a crer que a fotografia artística só poderia ser praticada no contexto das associações e clubes fotográficos, em obediência a regras claramente estabelecidas e compartilhadas ${ }^{68}$. A pesquisadora aponta ainda que os dois fotógrafos exatavam as qualidades da fotografia enquanto original. Valêncio de Barros, particularmente, é enfático a esse respeito:

(...) é na tiragem da prova que o sentimento ... a habilidade do fotógrafo vão interferir definitivamente. O negativo é produto da máquina, mas a prova, como o estilo, é do homem. Ela não é obra da matéria nem do acaso porque houve a colaboração do espírito e da vontade ${ }^{69}$.

O autor defende, em seguida, o emprego de intervenções manuais na cópia fotográfica por meio de técnicas tais como o bromóleo ou a goma bicromatada, de modo a camuflar a origem mecânica da fotografia e alçá-la ao patamar da arte, como pregavam a maioria dos adeptos do pictorialismo. Desse modo ele renega a pertinência da fotografia artística ser difundida por meio de reproduções como ocorria na exposição norte-americana. 
Em que pesem as diferenças de estilo individual entre as falas e o maior ou menor grau de adesão à estética pictorialista, tanto Jacob Polacow quanto Valêncio de Barros colocaram-se como porta-vozes de uma concepção de fotografia artística que, no exterior, já estava amplamente ultrapassada e no Brasil começara a ser colocada em xeque pelos fotógrafos pioneiros do Foto Cine Clube Bandeirante cerca de dois anos antes. Devemos considerar também que as contradições inerentes à prática da fotografia pictorialista numa cidade em processo de modernização acelerado como São Paulo, no final da década de 1940, não devem ter passado despercebidas aos visitantes da exposição norte-americana. Eles puderam ver ali imagens diretas e nítidas, que não buscavam mimetizar efeitos pictóricos, mas ressaltar as especificidades do registro fotográfico, a começar pela própria reprodutibilidade. Do mesmo modo, os temas fugiam do repertório tradicional e incluíam flagrantes de rua, arranha-céus, estruturas industriais, etc.

Caberia ressaltar, ainda, que por mais que a exposição fosse limitada pelo didatismo, pela ênfase na técnica e pelo tamanho reduzido das imagens, trazia a chancela do MoMA, primeiro museu de arte moderna a reconhecer oficialmente a fotografia como expressão artística. Não é possível avaliarmos a repercussão da mostra junto ao público leigo, no entanto, não nos parece casual o fato de que o VII Salão de Arte Fotográfica, organizado pelo Foto Cine Clube Bandeirante, um ano após a exposição norte-americana, aponte para uma mudança de rumo da fotografia praticada pelo Clube. É o que demonstra Lenzine, ao comparar os catálogos deste e do salão de 1947. Segundo ela, os textos teóricos publicados no boletim, a partir daquela data, apontam para a busca do Bandeirante por seu reconhecimento público como o lugar da prática da fotografia moderna no país ${ }^{70}$.

Ao que tudo indica, a exposição Fotografia Artística catalizou um debate já em curso sobre a superação da estética pictorialista pela fotografia moderna e teria contribuído para explicitar a estagnação do fotoclubismo brasileiro, em especial paulista. No momento em que a exposição norte-americana apresenta uma produção fotográfica de cunho modernista na Seção de Arte de uma instituição, cuja missão era difundir e colecionar arte moderna, acaba por evidenciar o isolamento da fotografia local em relação às artes ${ }^{71}$. Coincidência, ou não, dois anos depois Thomaz Farkas iria expor seu trabalho no recém-inaugurado Museu de Arte Moderna de São Paulo, na que seria a primeira de várias mostras de membros do Foto Cine Clube Bandeirante no circuito museológico da cidade ${ }^{72}$.

museu como instrumento político e veículo de comunicação de massa

A exposição Fotografia Criativa não foi a primeira exposição didática de fotografia produzida pelo MoMA para itinerância. Antes dela foram organizadas as mostras Functions of the camera (1939) e How to make a photogram (1942). $\bigcirc$ Departamento de Exposições Itinerantes, responsável por essas iniciativas, convidou dois fotógrafos para a organização das mostras, no caso Andreas Feininger e Laszlo Moholy-Nagy, respectivamente ${ }^{73}$. Ambos tinham grande
70. Ver Vanessa Lenzini (2008, p.68-78).

71. Permito-me aqui rever meu posicionamento a respeito dessa exposição a partir do diálogo com as pesquisas de Heloisa Espada (2006), Vanessa Lanzini (2008) e Annateresa Fabris (2012). Em artigo publicado anteriormente desconsiderei a importância da exposição para a fotografia que se produzia na década de 1940 em São Paulo. Cf. COSTA, 2010.

72. Ver Helouise Costa (2008).

73. Moholy-Nagy, que na ocasião era diretor da Escola de Design de Chicago, montou uma mostra que explicava o que era um fotograma, ensinava como fazê-lo e apresentava exemplos de autoria de Man Ray, bem como de professores e alunos da Escola, dentre os quais ele próprio. Segundo Diana Dobranszky (2008, v. 1, p. 148) essa exposição é citada em alguns documentos como Painting with light. 
74. O Departamento de Fotografia do MoMA foi inaugurado em 1940 e seu primeiro diretor foi Beaumont Newhall, que adaptou para a fotografia valores estéticos do campo da história da arte. Segundo Christopher Phillips, os critérios adotados para a incorporação de fotografias ao acervo do MoMA por Newhall foram: raridade, autenticidade, expressão pessoal e virtuosismo técnico. A sua gestão estendeu-se até março de 1946, quando ele pediu demissão, por discordar das novas diretrizes impostas para a fotografia. Para uma análise atualizada desse processo ver Ariane Pollet (2012).

75. Em inúmeros documentos de arquivo e publicações do MoMA Edward Steichen é designado como "Capitão Steichen".

76. Steichen organizou nesse período as exposições Road to Victory (1942) e Power in the Pacific (1944). Sobre as exposições de Edward Steichen no MoMA ver Christopher Phillips (1982).

77. Considera-se como vintage print a cópia fotográfica produzida pelo próprio fotógrafo, ou por alguém por ele autorizado e/ou supervisionado, a partir do negativo original, durante um certo período de tempo após o ato fotográfico. Essa extensão de tempo é motivo de controvérsia entre diferentes autores e pode abranger algumas semanas, meses ou mesmo anos (em geral de um a cinco). Uma definição simplificada pode ser encontrada no verbete prints em Mora (1998, p.166).

78. "O texto da exposição de fotografia foi enviado de volta por Steichen com muitas sugestões de revisão, com ênfase, particularmente, na ideia de 'inspirar o público' ao invés de forne- preocupação com a difusão e o ensino da fotografia, que consideravam menos como arte, no sentido estrito do termo, e mais como ferramenta de alargamento da percepção diante dos desafios da modernização. Na verdade, desde a adesão do MoMA ao esforço de guerra, os dirigentes do museu vinham abrindo cada vez mais espaço para exposições que não passavam pelo crivo do Departamento de Fotografia, como foi o caso destas ${ }^{74}$.

É nesse contexto que o fotógrafo Edward Steichen começou a colaborar com o MoMA, a convite de Nelson Rockefeller, no início dos anos 1940. Rockfeller buscava gerir o museu segundo uma mentalidade empresarial, que se consolidaria como característica dos museus privados nos Estados Unidos. Ele adota um programa de popularização das exposições e aparelhamento político do museu, tarefas para as quais Steichen seria um grande colaborador. $\bigcirc$ fotógrafo tinha larga experiência nos meios de comunicação de massas e intensa atuação comercial, além de exaltar com orgulho em seu currículo a colaboração com o exército norte-americano nas duas grandes guerras ${ }^{75}$.

As primeiras mostras organizadas por Edward Steichen no MoMA fizeram uso de reproduções fotográficas de grande formato, lançaram mão de sofisticados recursos cenográficos e mobilizaram o potencial comunicativo da imagem para a propaganda política ${ }^{76}$. Fica evidente assim o conflito que se estabeleceria entre Steichen e Beaumont Newhall, então diretor do Departamento de Fotografia, para quem as qualidades artísticas da fotografia só poderiam ser observadas nas fotografias ditas originais, ou seja, nas cópias fotográficas resultantes de tiragens autorais, as denominadas vintage prints ${ }^{77}$.

Uma correspondência datada de setembro de 1944, endereçada a Andreas Feininger, comprova que a mostra Fotografia Artística, em sua origem, teve a supervisão de Edward Steichen ${ }^{78}$. Isso só vem confirmar que a exposição estava inserida na nova orientação assumida pelo MoMA. No caso das exposições múltiplas a reprodutibilidade era um meio de ampliar o alcance do museu para além dos muros institucionais e das fronteiras do próprio país. Olivier Lugon afirma que esse tipo de preocupação não era raro no período:

Desde os anos de 1940, instituições tão distintas quanto o MoMA ou a revista Life, lançaramse na produção de "exposições múltiplas" feitas de painéis reprodutíveis, que podiam alcançar tiragens de muitas centenas e até mil exemplares, dando assim à exposição um poder de difusão digno dos novos meios de comunicação de massa ${ }^{79}$.

As exposições múltiplas materializaram um certo ideal liberal de democratização da arte e podem ser entendidas como integrantes de um conjunto de ações afinadas com o objetivo do governo norte-americano de consolidar a hegemonia cultural do país em sintonia com a sua nova posição no mapa geopolítico do pós-guerra. No momento em que o Brasil se preparava para criar os seus primeiros museus modernos, é sintomático que o MoMA tenha se empenhado em difundir aqui uma certa concepção de fotografia artística por meio de uma mostra didática constituída de fotos pertencentes a seu acervo. 
A exposição Fotografia Artística levantou a bandeira da força da criatividade individual como possibilidade de qualquer pessoa ter acesso ao fazer artístico. Além disso, apostou no poder da fotografia de transpor as fronteiras geográficas por meio da reprodutibilidade e as fronteiras culturais por intermédio de seu suposto estatuto de linguagem universal, aparentemente inteligível em qualquer contexto. Como nos ensina a mostra norte-americana apresentada em São Paulo, legitimidade artística e legitimidade política caminhavam juntas naqueles anos conturbados.

\section{REFERÊNCIAS}

\section{FONTES ARQUIVÍSTICAS}

The Museum of Modern Art Archives, Nova York: Department of Circulating Exhibitions Records. Serie II: Exhibitions, 1931-1958. CE II.1.49.1 e CE II.1.49.1.1

\section{LIVROS, ARTIGOS E TESES}

ADAMS, Ansel. A cópia. São Paulo: Ed. Senac, 2000. O negativo. São Paulo: Ed. Senac, 2001. A câmera. São Paulo: Ed. Senac, 2006.

D'ÁVILA, João Pires. Fala o editor. O nosso número especial. Íris, São Paulo, v. 1, n.6, p. 1011, jun. 1947.

BARROS, Valêncio. A fotografia é arte?. Foto-Cine Clube Bandeirante Boletim, São Paulo, n. 16, p. 2-3, ago. $1947 \mathrm{a}$.

BARROS, Valêncio. A fotografia é arte?. (parte II). Foto-Cine Clube Bandeirante Boletim, São Paulo, n. 17, p. 5-7, set. 1947b.

BARROS, Valêncio. A fotografia é arte?. (parte III). Foto-Cine Clube Bandeirante Boletim, São Paulo, n. 18, p. 4-5, 17, out.1947c.

BEE, Harriet; ELLIGOTT, Michelle (ed.). The Art in Our Time. A chronicle of The Museum of Modern Art. New York: The Museum of Modern Art, 2004.

BUENO, Maria Lúcia. Artes plásticas no século XX. Modernidade e globalização. Campinas (SP): Editora da Unicamp, 1999.

CAMARGO, Monica Junqueira de; MENDES, Ricardo. Fotografia: cultura e fotografia paulistana no século XX. São Paulo: Secretaria Municipal de Cultura, 1992. cer informações técnicas que possam ser encontradas nos manuais da Kodak (...). Isso significa incluir alguns painéis, mas manter quase intacto o que nós já temos". Cf. The Museum of Modern Art Archives, NY, CE II.1.49.1.

79. Ver Olivier Lugon (2012), p. 11. Tradução da autora. 
CHEVRIER, Jean-François. Andreas Feininger, fotógrafo-anatomista. In: FUNDACIÓN Juan March. Andreas Feininger (1906-1999). Madrid: 2008. p. 50-53.

COMPUR. A Exposição de Fotografias Artísticas. Foto-Cine Clube Bandeirante Boletim, São Paulo, n. 15, p. 11, jul. 1947.

COSTA, Helouise. Da fotografia como arte à arte como fotografia: a experiência do Museu de Arte Contemporânea da USP na década de 1970. Anais do Museu Paulista: História e Cultura Material, São Paulo, v.16. n.2, p. 131-173, jul.-dez. 2008.

Imagens em trânsito: lições de uma mostra norte-americana em São Paulo (1947). ANAIS DO XXX COLÓQUIO DO COMITÊ BRASILEIRO DE HISTÓRIA DA ARTE, São Paulo, p. 154-161, 2010. CD. Disponível também em: <http://www.cbha.art.br/coloquios/2010/ anais/site/pdf/cbha_2010_Costa_Helouise_art.pdf>.

A invenção da revista ilustrada. In: BURGI, Sérgio; COSTA, Helouise. As origens do fotojornalismo no Brasil. Um olhar sobre O Cruzeiro. Rio de Janeiro: Instituto Moreira Salles, 2012. p. 202-323.

COSTA, Helouise; SILVA, Renato Rodrigues da. A fotografia moderna no Brasil. São Paulo: CosacNaify, 2004.

DOBRANSZKY, Diana. A legitimação da fotografia no museu de arte: o Museum of Modern Art de Nova York e os anos Newhall no Departamento de Fotografia. 2v. Tese (Doutorado) Universidade Estadual de Campinas / Instituto de Artes, Campinas, 2008.

ESPADA, Heloisa. Panamericanismo e Straight Photography como impulsos da fotografia moderna paulistana. Boletim - Grupo de Estudos do Centro de Pesquisas em Arte E Fotografia, São Paulo, v.1, p. 48-57, 2006.

FABER, John. Great News Photos and the Stories behind Them. New York: Dover, 1978.

FABRIS, Annateresa. Um "fogo de palha aceso": considerações sobre o primeiro momento do museu de arte moderna de São Paulo". In: FABRIS, Annateresa; OSORIO, Luiz Camillo. MAM 60. São Paulo: Museu de Arte Moderna de São Paulo, 2008. p. 14-89.

Uma sensação estranha, que faz pensar. In: SAMAIN, Etienne (ed.). Como pensam as imagens. Campinas (SP): Unicamp, 2012. p. 175-189.

FARKAS, Thomas. Notas de viagem. São Paulo: CosacNaify, 2006.

FEININGER, Andreas. Pest Portraits. Life, Nova York, v.28, n.12, p. 109-112, 20/03/1950. Skull, Ribs Act as Armor. Life, Nova York, v.33, n.14, p. 130-131, $06 / 10 / 1952$.

Cliffs, 1955. The Creative Photographer. New Jersey: Prentice-Hall Inc. Englewood FUNDACIÓN JUAN MARCH. Andreas Feininger, 1906-1999. Madrid: Fundación Juan March, 2008. 
GEIRINGER, Frederico R. A expansão da fotografia nos Estados Unidos. Íris, São Paulo, v. 1, n.6, p. 16-18, jun. 1947.

. À margem do ciclo de conferências. Íris, São Paulo, v. 1, n.7, p.16-25, jul. 1947.

GONÇALVES, Lisbeth Rebollo. Os grupos: a década de 40. São Paulo: MLS, 1976.

Sérgio Milliet, crítico de arte. São Paulo: Edusp/Perspectiva, 1992.

LAVÉDRINE, Bertrand. (Re) Cônnaitre et conserver les photographies anciennes. Paris: CTHS, 2007.

LENZINI, Vanessa Sobrino. Noções de moderno no Foto-Cine Clube Bandeirante: fotografia em São Paulo (1948). Dissertação (Mestrado) - Universidade Estadual de Campinas / Instituto de Filosofia e Ciências Humanas, Campinas, 2008.

LUGON, Olivier (dir). Exposition et médias: Photographie, cinéma, télévision. Lausanne: L’Âge d'homme, 2012.

MARTINS, Ana Luísa; SILVA, José Armando Pereira da (ed.). Luís Martins: um cronista de arte em São Paulo nos anos 1940. São Paulo: Museu de Arte Moderna de São Paulo, 2009.

MILLIET, Sérgio. Pintura norte-americana. São Paulo: Martins Fontes, 1943.

MORA, Gilles. Photo Speak. A Guide to the Ideas, Movements, and Techiniques of Photography, 1839 to the present. New York: Abbeville, 1998.

NASCIMENTO, Ana Paula. MAM: Museu para a metrópole: a participação dos arquitetos na organização inicial do Museu de Arte Moderna de São Paulo. Dissertação (Mestrado) Universidade de São Paulo / Faculdade de Arquitetura e Urbanismo, São Paulo, 2003.

NEWHALL, Beaumont. Focus. Memoirs of a Life in Photography. Boston: Bulfinch, 1993.

OlIVEIRA, Rita Alves. A Bienal de São Paulo: forma histórica e produção cultural. Tese (Doutorado) - Pontifícia Universidade Católica de São Paulo / Faculdade de Ciências Sociais, São Paulo, 2001.

PHILLIPS, Christopher. The Judgment Seat of Photography. October, Cambridge (Mass.), v.22., p. 27-63, 1982.

POLACOW, Jacob. Pictorialismo em arte fotográfica (parte I). Foto-Cine Clube Bandeirante Boletim, São Paulo, n.15, p. 2-4, jul. 1947a.

Pictorialismo em arte fotográfica (parte II). Foto-Cine Clube Bandeirante Boletim, São Paulo, n.16, p. 05-06, ago. 1947b;

. Pictorialismo em arte fotográfica (parte III). Foto-Cine Clube Bandeirante Boletim, São Paulo, n.17, p. 05-06. set. 1947c.

POLLET, Ariane. Mass media et musée d'art: le MoMA en crise, 1940-1947. In: LUGON, Olivier (ed.). Exposition et media. Photographie, cinéma, télévision. Lausanne: L'Age d'Homme, 2012. p.132-134.

Annals of Museu Paulista. v. 22. n.1. Jan.-Jun. 2014. 
REPRODUÇÃo dos quadros expostos na Biblioteca Municipal de São Paulo. Íris, São Paulo, n.6, p. 29-40, jun. 1947.

SCACHERI, Mabel. Museum Show Aimed at Nonphotographer. World Telegram, New York, 09/03/1945.

STANISZEWSKI, Mary Anne. A History of Exhibition Instalations at the Museum of Modern Art. Cambridge (Mass.) Londres: The MIT Press, 1998.

THE MUSEUM of Modern Art Bulletin, Nova York, v. XXI, n. 3-4, verão 1954. Circulating Exhibitions, 1931-1954.

TOTA, Antonio Pedro. O imperialismo sedutor. A americanização do Brasil na época da Segunda Guerra. São Paulo: Companhia das Letras, 2000.

Artigo apresentado em 14/03/2010. Aprovado em 26/05/2014. 